\title{
A survey of problems in the antibiotic treatment of gonorrhoea With special reference to South-East Asia
}

\author{
R. R. W I L L COX \\ Consultant Venereologist, St. Mary's Hospital, London, W.2 \\ Member WHO Expert Panel on the Venereal Infections and Treponematoses
}

A CRISIS is being reached in the treatment of gonorrhoea in many countries of S.-E. Asia owing to the increased resistance of the gonococcus to antibiotics. The golden era of the antibiotic treatment of gonorrhoea is over, now that the limits of single session therapy are drawing near in a number of areas, and high and multiple doses of penicillin, or other more expensive antibiotics, are coming to be required with consequent epidemiological and economic disadvantages. Moreover, the possibility of the general spread of the more resistant organisms to other areas of the world is a matter of expressed concern (f. Amer. med. Ass., 1967).

\section{Causes of failure other than resistance}

Developing resistance is not the only reason for failure of antibiotics (Carpenter, 1961; Stepniak,

Paper presented to Second WHO Regional Seminar on V.D. Control, Manila, Philippines, in December, 1968

\section{TABLE I Causes of penicillin failure}

1961; Willcox, 1961). Other causes, listed in Table I, include:

(i) Re-infection-for there are no adequate criteria to distinguish this from relapse although the penicillin sensitivity of the organism found in cases of recurrence is helpful in this respect (Curtis and Wilkinson, 1958; Gjessing and Ödegaard, 1962; Reyn and Bentzon, 1963);

(ii) Confusion with non-gonococcal urethritis;

(iii) Accessibility of the organism to the antibiotic;

(iv) Individual variations in the serum and therefore in the tissue levels of penicillin.

A number of these factors may well act in conjunction. A less sensitive organism which is partly inaccessible will respond badly to a border-line level of penicillin at the tissue site. Nevertheless, in all circumstances, the antibiotic sensitivity of the organism is of basic importance.

No failure at all $\quad \frac{\text { Re-infection }}{\text { Misdiagnosis }}$

(b) Staphylococci (Tawes, 1966) or Mimeae (Gangarosa and Cary, 1960; Svihus, Lucero, Mikolaczyk, and Carter, 1961; Sanders, Pelczar, and Hoefling, 1962) mistaken for gonococcus

Use of wrong dose, preparation, or deteriorated product

Faulty injection technique

Greater protein-binding of some penicillins (Knudsen, 1964; Rolinson, 1964)

Individual variations in serum levels

Too rapid destruction and elimination of penicillin

Insufficient level of penicillin at infection site

Walled-off focus (Carpenter, 1961; Rees, 1952)

Shielded phagocytosed gonococci (Thayer and others, 1957; Rohde and Meyer-Rohn, 1961)

Possible assumption of ' $L$ ' forms by gonococcus (Barile, Van Zee, and Yaguchi, 1959)

Protein-binding of penicillin in tissues (Rolinson, 1964)

Destruction of penicillin by local penicillinase-producing organisms, e.g. saprophytic staphylococci (Gentele, Lagerholm, and Lodin, 1960; Sanders and others, 1962; Kjellander and Finland, 1963);

although there is little support for this hypothesis (Lagerholm, Lodin, and Nyström, 1966; Tawes, 1966), the use of penicillinase-resistant penicillins has been suggested (Ho and Chang, 1967) 


\section{Sensitivity of the gonococcus to antibiotics} TO PENICILLIN

\section{Emergence of less sensitive strains}

Increases in the proportions of 'circulating' strains of gonococci less sensitive to penicillin have been noted for more than a decade in many parts of the world:

Europe (Reyn, Korner, and Bentzon, 1958; Reyn and Bentzon, 1963; Durel, 1961 ; Durel, Roiron, and Delouche, 1961; Medical Research Council, 1961 ; Roiron, RasettiNicod, and Durel, 1961; Rantasalo, 1962; Röckl, 1962; Schmidt, 1962; Vermeer and Schaap, 1962; Gjessing and Ödegaard, 1962; Gjessing, 1963; Gästrin and Kallings, 1964; Anğ and Oner, 1965; Grin and Karlovac, 1965; Hejzlar and Výmola, 1965; Ödegaard and Gjessing, 1967; Warren, 1968; Rees, 1967);

U.S.A. (Thayer, Field, Magnuson, and Garson, 1957; Thayer, Samuels, Martin, and Lucas, 1965);

Canada (Snell, Norris, and Strong, 1963);

Greenland (Lomholt and Berg, 1966);

India (Chacko and Yogeswari, 1966);

South-East Asia and the Western Pacific Region of WHO (Tai and Han, 1960; WHO, 1963; Reyn, 1968; Ho and Chang, 1967), including Australia (Smith and Levey, 1967).

Both the proportion of the less sensitive strains and the extent of their insensitivity have increased (Thayer and others, 1965) and a good correlation has been demonstrated between treatment failure and the less sensitive organisms (amongst others by Curtis and Wilkinson, 1958; Cradock-Watson, Shooter, and Nicol, 1958; Gjessing and Ödegaard, 1962; Rantasalo, 1962; Reyn and Bentzon, 1963; Snell and others, 1963; Sokoloff and Goldstein, 1963; Björnberg, 1964; Meyer-Rohn, 1964; Bøggild, 1965; Juhlin and Krook, 1965; Schmidt and Roholt, 1965; Lejman, Kowarz-Sokolowska, Stapiński, and Starzycki, 1965; Chacko and Yogeswari, 1966).

In recent years, some strains requiring 2 units $/ \mathrm{ml}$. or more of penicillin have been encountered in Europe (Hejzlar and Výmola, 1965; Gjessing and Ödegaard, 1965), and one has been reported with an estimated minimum inhibitory concentration of 4.8 to 5.8 units $/ \mathrm{ml}$. (Aepinus, 1965).

\section{Difficulties in comparison of data}

Lack of standardization of methods, techniques (Reyn, Bentzon, and Ericsson, 1963), and reporting has made exact comparison between countries difficult in spite of efforts by WHO to establish standardized methods (WHO, 1963). Some authors estimate the minimum inhibitory concentration (MIC), others the concentration required to inhibit half of the organisms $\left(\mathrm{IC}_{50}\right)$. Definitions of the MIC of less sensitive strains vary between 0.05 and 0.125 units $/ \mathrm{ml}$. but some calculate in units $/ \mathrm{ml}$. and others in $\mu \mathrm{g} . / \mathrm{ml}$. Moreover, many reports refer to mixed problem and routine strains, between which considerable differences in resistance may be expected.

Nevertheless, it is generally agreed that the distribution of organisms of lessened sensitivity varies both in space and in time, not only between countries (Ziprkowski, Krakowski, and Roubenoff, 1961; WHO, 1963) but within a particular country (Medical Research Council, 1961 ; Kallings and Gästrin, 1966) and independently of the seasons (Evans, 1966).

The sensitivities now prevailing at two hospitals in London are shown in Table II. At one of these centres, although the incidence of unselected strains requiring 0.125 units $/ \mathrm{ml}$. or more of penicillin was 20.3 per cent., only 0.5 per cent. required 0.5 units.

TABLE II Range of penicillin sensitivities of gonococci in London

\begin{tabular}{|c|c|}
\hline Hospital & $M I C(u . / m l)$. \\
\hline \multirow[t]{2}{*}{$\begin{array}{l}\text { St. Mary's } \\
\text { (Leigh, 1968) }\end{array}$} & $\begin{array}{l}0.025 \text { and less } \\
0.05 \\
0.1 \\
0.2 \\
0.5 \\
\text { Over } 0.5\end{array}$ \\
\hline & Total \\
\hline \multirow[t]{2}{*}{$\begin{array}{l}\text { The Londont } \\
\text { (Wilkinson, 1968) }\end{array}$} & $\begin{array}{l}0.008 \\
0.015 \\
0.03 \\
0.06 \\
0.125 \\
0.25 \\
0.5\end{array}$ \\
\hline & Total \\
\hline
\end{tabular}

\begin{tabular}{rr} 
No. & Per cent. \\
\hline 107 & $44 \cdot 2$ \\
35 & 14.5 \\
53 & $21 \cdot 9$ \\
25 & $10 \cdot 3$ \\
9 & 3.7 \\
13 & $5 \cdot 4$ \\
\hline 242 & $100 \cdot 0$ \\
\hline 90 & 42.5 \\
35 & 16.5 \\
18 & 8.5 \\
26 & 12.2 \\
31 & 14.6 \\
11 & 5.2 \\
1 & 0.5 \\
\hline 212 & 100.0
\end{tabular}

* Mainly unselected but some problem strains-plate dilution method †Unselected strains-tube dilution method

What can be achieved clinically with single doses of various penicillin preparations in London is shown $\widetilde{\sigma}$ in Table III (opposite).

\section{TO OTHER ANTIBIOTICS}

\section{Streptomycin}

Parallel with the lessened sensitivity to penicillin the incidence of strains completely resistant to streptomycin has developed even more rapidly (Table IV, opposite; see also Fig. 1).

Although this was not at first apparent (Curtis and Wilkinson, 1958), the streptomycin resistant strains are now nearly always less sensitive to penicillin and vice versa (Reyn, 1963; Thayer and others, 1965; Grin and Karlovac, 1965; Chacko and Yogeswari, 1966; Ödegaard and Gjessing, 1967; Wilkinson, Race, and Curtis, 1967; Reyn and Bentzon, 1968). 
TABLE III Results obtained by various penicillins using single-session techniques on male patients in London (See Willcox, 1968)

\begin{tabular}{|c|c|c|c|c|c|c|}
\hline \multirow[b]{2}{*}{ Antibiotic } & \multirow[b]{2}{*}{ Dose } & \multirow[b]{2}{*}{ Route } & \multirow[b]{2}{*}{ No. treated } & \multirow[b]{2}{*}{ No. followed } & \multicolumn{2}{|c|}{ Failures } \\
\hline & & & & & No. & Per cent. of those followed \\
\hline $\begin{aligned} \text { Procaine penicillin } & (1964) \\
& (1966-67) \\
& (1966-67) \\
& (1968-69) \ddagger \\
& (1968-69) \ddagger\end{aligned}$ & $\begin{array}{l}1.2 \mathrm{~m} . \mathrm{u} . \\
1.2 \mathrm{~m} . \mathrm{u} . \\
2.4 \mathrm{~m} . \mathrm{u} . \\
1.2 \mathrm{~m} . \mathrm{u} . \\
1.2 \mathrm{~m} . \mathrm{u} . \text { plus } \\
\text { probenecid }\end{array}$ & $\begin{array}{l}\text { Injection } \\
\text { Injection } \\
\text { Injection } \\
\text { Injection } \\
\text { Injection }\end{array}$ & $\begin{array}{l}279 \\
238 \\
280 \\
307 \\
307\end{array}$ & $\begin{array}{l}207 \\
200 \\
240 \\
253 \\
256\end{array}$ & $\begin{array}{l}23 \\
17 \\
14 \\
36 \\
17\end{array}$ & $\begin{array}{c}11 \cdot 1 \\
8 \cdot 5 t \\
5 \cdot 8 t \\
14 \cdot 2 \\
6 \cdot 6\end{array}$ \\
\hline Benzathine penicillin & $0.6-4.8 \mathrm{~m} . \mathrm{u}$ & Oral & 46 & 44 & 16 & $36 \cdot 4$ \\
\hline Phenoxymethyl penicillin & $1 \cdot 25-1 \cdot 875 \mathrm{~g}$ & Oral & 43 & 37 & 5 & $13 \cdot 5$ \\
\hline Phenethicillin & $1.0 \mathrm{~g}$ & Oral & 25 & 22 & 6 & $27 \cdot 3$ \\
\hline Cloxacillin & $1.0-1.5 \mathrm{~g}$ & Oral & 20 & 16 & 6 & $37 \cdot 5$ \\
\hline Ampicillin & $\begin{array}{l}0.5-1.0 \mathrm{~g} \\
250-500 \mathrm{mg} .\end{array}$ & $\begin{array}{l}\text { Oral } \\
\text { Injection }\end{array}$ & $\begin{array}{l}200 \\
106\end{array}$ & $\begin{array}{r}174 \\
83\end{array}$ & $\begin{array}{l}26 \\
23\end{array}$ & $\begin{array}{l}14 \cdot 9 \\
27 \cdot 7\end{array}$ \\
\hline Cephaloridine ${ }^{\star}$ & $2.0 \mathrm{~g}$ & Injection & 40 & 35 & 6 & $17 \cdot 1$ \\
\hline
\end{tabular}

*Csonka and Murray (1967)

$t$ (The difference between these readings is not statistically significant. It is calculated that for them to be so 725 cases would have to be treated in both series-and possibly up to $1,000-$ Rose, 1968)

†Cobbold, Morrison, Spitzer, and Willcox (1970)

TABLE IV Mounting resistance to streptomycin in London (in male patients given 1 g.) (See also Fig. 1) (see Spitzer and Willcox, 1968)

\begin{tabular}{|c|c|c|c|c|}
\hline \multirow{2}{*}{ Year } & \multirow{2}{*}{ No. treated } & \multirow{2}{*}{ No. followed } & \multicolumn{2}{|c|}{ Failures } \\
\hline & & & No. & $\begin{array}{l}\text { Percentage of } \\
\text { those followed }\end{array}$ \\
\hline $\begin{array}{l}1951 \\
1956 \\
1961 \\
1966\end{array}$ & $\begin{array}{r}42 \\
55 \\
224 \\
130\end{array}$ & $\begin{array}{r}35 \\
46 \\
181 \\
104\end{array}$ & $\begin{array}{r}3 \\
5 \\
27 \\
23\end{array}$ & $\begin{array}{r}8.5 \\
10 \cdot 2 \\
14.9 \\
31.7\end{array}$ \\
\hline
\end{tabular}

(At the most recent rate of increase the failure rate would reach 85 per cent. by 1971)

\section{Tetracycline}

A lessened sensitivity to the tetracyclines has also arisen in many areas, including the USA (Thayer and others, 1965); Europe (Reyn, 1961; Schmidt, 1962; Anğ and Oner, 1965); Greenland (Lomholt and Berg, 1966), and the Philippines, where no less than 49 per cent. of strains have been so reported (WHO, 1963). Furthermore, two-thirds of streptomycin resistant strains, nearly all of which are less sensitive to penicillin, have been shown to be also less sensitive to the tetracyclines (Reyn, 1963).

\section{Chloramphenicol}

Few signs of resistance have been reported (Gästrin and Kallings, 1964; Ödegaard and Gjessing, 1967); the use of this drug has been restricted, but nevertheless strains which are less sensitive to chloramphenicol are also less sensitive to penicillin (Chacko and Yogeswari, 1966).

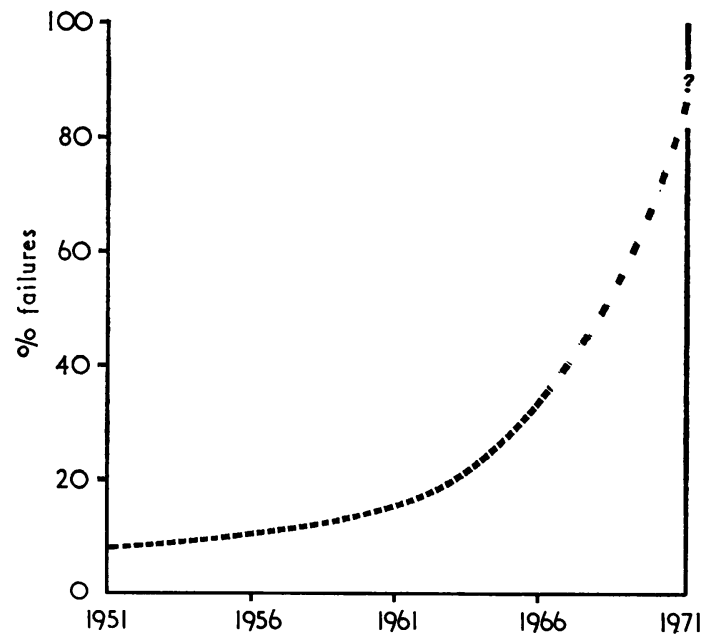

F I G. 1 Failure rates with streptomycin in London (curve hypothetical 1966-71) (Table IV: Spitzer and Willcox, 1968)

\section{Erythromycin}

There is no evidence of widespread resistance to erythromycin (Ödegaard and Gjessing, 1967), although high failure rates have been noted with this antibiotic in cases failing to respond to penicillin (Lyng, 1963).

\section{Spiramycin}

Organisms less sensitive to this antibiotic are likewise usually less sensitive to penicillin (Reyn and Bentzon, 1968), although spiramycin resistance may not be 
demonstrable in vitro (Schmidt, Niordson, Reyn, and Bentzon, 1965).

Some results obtained in London by single dose techniques with antibiotics other than penicillin are shown in Table V.

\section{SITUATION IN SOUTH-EAST ASIA}

\section{Clinical data}

In the Far East high failure rates to penicillin (23-29 per cent.) were early reported after doses which were large for that era (Bodenbender, 1960; Smedley, 1960). The worst results were obtained with depot preparations and in Korea a 40 per cent. failure rate was noted with three daily injections of 600,000 PAM (Sabath and Kivlahan, 1961). Even with the same dose of aqueous procaine penicillin given daily for 4 to 7 days, failure rates of 10 to 20 per cent. (Epstein, 1959; Mead, Moon, and Bean, 1960; Staheli, 1964) and later of no less than 54.5 per cent. were observed; even if 0.9 mega unit was administered daily for one week there were failures in 36.2 per cent. of cases (Stebbins, 1967). Recently in Australia 12 per cent. of cases in women failed to respond when 1 mega unit procaine penicillin was injected daily for 10 days (Wren, 1967). Moreover, single injections of 2.4 mega units of this preparation have been followed by a failure rate in males of 28.6 per cent. (Holmes, Johnson, and Floyd, 1967a; see Table VI).
TABLE VI Results obtained in males against the 'Eastern gonococcus' (Holmes and others, 1967a)

\begin{tabular}{|c|c|c|c|}
\hline \multirow{2}{*}{ Schedule } & \multirow{2}{*}{$\begin{array}{l}\text { No. of } \\
\text { cases }\end{array}$} & \multicolumn{2}{|c|}{ Failures } \\
\hline & & No. & $\begin{array}{l}\text { Percentage of } \\
\text { those followed }\end{array}$ \\
\hline $\begin{array}{l}\text { Procaine penicillin } 2.4 \text { m.u. by } \\
\text { injection }\end{array}$ & 63 & 18 & $28 \cdot 6$ \\
\hline $\begin{array}{l}\text { Ditto } \\
\text { plus probenecid } 2.5 \mathrm{~g} \text {. in five } \\
\text { doses from }-1 \text { to }+18 \mathrm{hrs}\end{array}$ & 58 & 1 & 1.7 \\
\hline $\begin{array}{l}\text { Tetracycline hydrochloride } 1.5 \mathrm{~g} \text {. } \\
\text { plus sixteen oral doses of } 500 \mathrm{mg} \text {. } \\
6 \text {-hrly }\end{array}$ & 30 & 0 & 0 \\
\hline
\end{tabular}

\section{Laboratory data}

The incidence of increased resistance of the gono- $\vec{\nabla}$ coccus to antibiotics is much more pronounced in $\vec{\bullet}$ South-East Asia and the Western Pacific Region of WHO than in most other areas. In a WHO study in the Philippines 100 per cent. of one series of strains were found to have reduced sensitivity to penicillin (WHO, 1963).

Recent results of sensitivity tests in the Far East are given in Tables VII to XIV (opposite and overleaf).

TABLE V Single session techniques with antibiotics other than penicillin in male patients in London

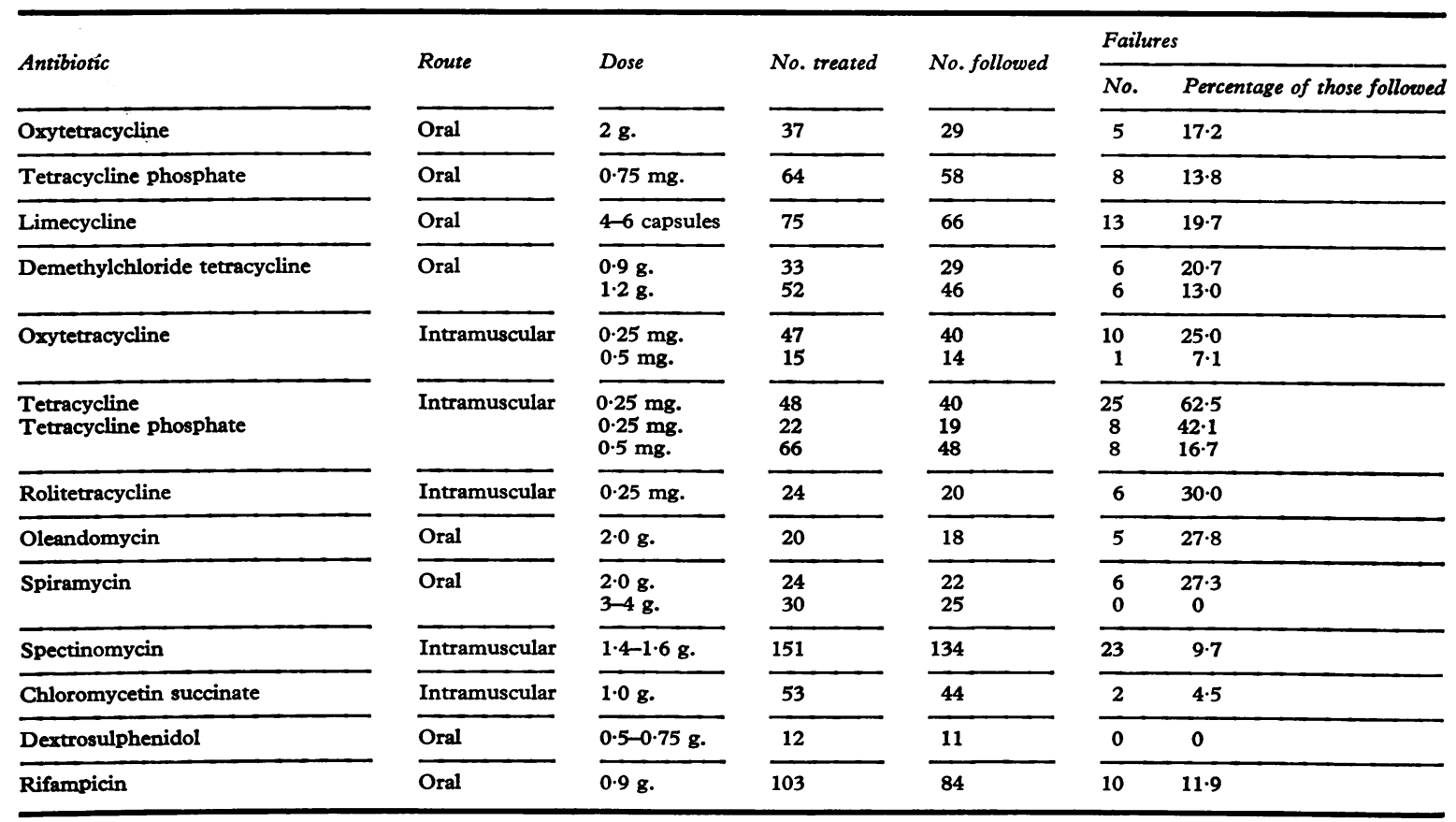


TABLE VII Penicillin susceptibility of the gonococcus in Australia (Smith and Levey, 1967)*

\begin{tabular}{|c|c|c|c|}
\hline$M I C(u . / m l)$. & No. of strains & Per cent. & $\begin{array}{l}\text { Cumulative } \\
\text { percentage }\end{array}$ \\
\hline $\begin{array}{l}0.05 \\
0.1 \\
0.5 \\
1.0 \\
2.5\end{array}$ & $\begin{array}{r}58 \\
9 \\
27 \\
9 \\
1\end{array}$ & $\begin{array}{r}55.8 \\
8.6 \\
26.0 \\
8.6 \\
1.0\end{array}$ & $\begin{array}{r}55 \cdot 8 \\
64 \cdot 4 \\
90 \cdot 4 \\
99 \cdot 0 \\
100 \cdot 0\end{array}$ \\
\hline Total & 104 & $100 \cdot 0$ & $100 \cdot 0$ \\
\hline
\end{tabular}

«Nature of strains unstated: probably mixed problem and unselected strains

Results for Australia are given in Table VII, for unselected and mixed strains from prostitutes in
Taiwan in Tables VIII and IX, and for largely selected strains examined at the WHO Neisseria Centre in Copenhagen (from Thailand, Hong Kong, South Vietnam, and Taiwan) in Tables X, XI, XII, $X I I I$, and XIV. The recent findings are compared with the earlier results in Ceylon and the Philippines in Table XI (overleaf).

\section{(a) Penicillin}

The data further illustrate lack of conformity in presentation between the three series, and varying sensitivity findings in different countries (Table $\mathbf{X}$ ) and in different areas in the same country (Table VIII). Nevertheless, a high proportion of less sensitive organisms is noted even in unselected strains. In

TABLE VIII Percentage MIC of penicillin $G$ for selected and unselected strains of gonococci from prostitutes in Taiwan (Ho and Chang, 1967)

\begin{tabular}{|c|c|c|c|c|c|c|c|c|c|c|}
\hline Area & \multicolumn{2}{|c|}{ Strains } & \multicolumn{8}{|c|}{$M I C\left(u_{.} / m l .{ }^{\star}\right)$} \\
\hline $\begin{array}{l}\text { Keeling } \\
\text { Wan-hua (Taipei) }\end{array}$ & $\begin{array}{l}14 \\
22\end{array}$ & $\begin{array}{l}\text { Unselected } \\
\text { Unselected }\end{array}$ & $\begin{array}{l}0 \\
0\end{array}$ & $\begin{array}{c}0 \\
13 \cdot 6\end{array}$ & $\begin{array}{l}0 \\
0\end{array}$ & $\begin{array}{l}7 \cdot 1 \\
0\end{array}$ & $\begin{array}{r}7 \cdot 1 \\
13 \cdot 6\end{array}$ & $\begin{array}{l}42 \cdot 9 \\
36 \cdot 4\end{array}$ & $\begin{array}{l}42 \cdot 9 \\
36 \cdot 4\end{array}$ & $\begin{array}{l}100 \cdot 0 \\
100 \cdot 0\end{array}$ \\
\hline Total & 36 & Unselected & 0 & $8 \cdot 3$ & 0 & $2 \cdot 8$ & $11 \cdot 1$ & $38 \cdot 9$ & $38 \cdot 9$ & $100 \cdot 0$ \\
\hline Yen-ping (Taipei) & 23 & Selected & 0 & $4 \cdot 3$ & $8 \cdot 7$ & $13 \cdot 0$ & $13 \cdot 0$ & $34 \cdot 8$ & $26 \cdot 1$ & $100 \cdot 0$ \\
\hline
\end{tabular}

$\star 2$ units are equivalent to $1 \cdot 2 \mu \mathrm{g}$.

TABLE IX Percentage MIC of other antibiotics for 59 gonococcal strains from prostitutes in Taiwan (Ho and Chang, 1967)

Antibiotic

Ampicillin

Cephaloridine

Oxacillin

Cloxacillin

Tetracycline

Chlortetracycline

Demethylchlortetracycline

Sulfasymazine

$M I C(\mu g . / m l$.

\begin{tabular}{lcrrrrrr}
\hline 50 or more & 25 & 12.5 & 6.25 & 3.2 & 1.6 & 0.8 or less & Total \\
\hline 0 & 0 & \multicolumn{1}{c}{0} & \multicolumn{1}{c}{0} & 5.1 & 20.3 & 74.6 & 100.0 \\
0 & 3.4 & 10.2 & 22.0 & 39.0 & 18.6 & 6.8 & 100.0 \\
1.7 & 10.2 & 13.6 & 25.4 & 20.3 & 16.9 & 11.9 & 100.0 \\
3.4 & 10.2 & 8.5 & 15.3 & 18.5 & 33.9 & 10.2 & 100.0 \\
\hline 3.4 & 1.7 & 1.7 & 5.1 & 23.7 & 33.9 & 30.5 & 100.0 \\
5.1 & 18.5 & 22.0 & 25.4 & 11.9 & 15.3 & 1.7 & 100.0 \\
6.8 & 6.8 & 3.4 & 5.1 & 23.7 & 40.7 & 13.6 & 100.0 \\
\hline 40.7 & 18.5 & 6.8 & 5.1 & 15.3 & 6.8 & 6.8 & 100.0
\end{tabular}

TABLE X Range of susceptibility of gonococcus to antibiotics in S.E. Asia ${ }^{\star}$ (Data from Reyn, 1968) (MIC values approximately twice as high)

\begin{tabular}{|c|c|c|c|c|c|}
\hline Area & No. of strains & $\begin{array}{l}\text { Penicillin }\left(I C_{50}\right) \\
(u . / m l .)\end{array}$ & $\begin{array}{l}\text { Streptomycin }\left(I C_{50}\right) \\
(\mu g . / m l .)\end{array}$ & $\begin{array}{l}\text { Tetracycline }\left(I C_{50}\right) \\
(\mu g . / m l .)\end{array}$ & $\begin{array}{l}\text { Spiramycin }\left(I C_{50}\right) \\
(\mu g . / m l .)\end{array}$ \\
\hline $\begin{array}{l}\text { Thailand } \\
\text { Hong Kong } \\
\text { Taiwan } \\
\text { South Vietnam }\end{array}$ & $\begin{array}{r}12 \\
16 \\
9 \\
6\end{array}$ & $\begin{array}{l}0.044-2.8 \\
0.03-2.8 \\
0.35-1.68 \\
0.59-2.4\end{array}$ & $\begin{array}{l}>\text { or }<25 \\
<5->1,000 \\
<5->1,000 \\
<5->2,000\end{array}$ & $\begin{array}{l}0.33-2.60 \\
0.28-1.60 \\
0.28-2.26 \\
0.8-1.9\end{array}$ & $\begin{array}{l}0.33-1.90 \\
0.40-3.20 \\
0.86-2.68 \\
0.95-2.26\end{array}$ \\
\hline $\mathrm{IC}_{50}$ range & 43 & $0.03-2 \cdot 8$ & $<5->2,000$ & $0 \cdot 28-2 \cdot 60$ & $0 \cdot 33-3 \cdot 20$ \\
\hline Approx. MIC range & & $0.006-5.6$ & $<10->2,000$ & $0.56-5 \cdot 20$ & $0.66-6.40$ \\
\hline
\end{tabular}

*Mixed problem and unselected strains examined at WHO Neisseria Centre, Copenhagen 
TABLE XI Incidence of lessened sensitivity of gonococcus to antibiotics in S.E. Asia (Data from Reyn, 1968*) (MIC values approximately twice as high) (see also Fig. 3)

\begin{tabular}{|c|c|c|c|c|c|c|c|c|c|}
\hline \multirow{2}{*}{ Area } & \multirow{4}{*}{ No. of strains } & \multicolumn{8}{|c|}{ Antibiotics } \\
\hline & & \multirow{2}{*}{\multicolumn{2}{|c|}{$\begin{array}{l}\text { Penicillin } \\
\text { IC }{ }_{50} \\
(0.088 \text { units } / \mathrm{ml} .) \\
(0.053 \mu \mathrm{g} . / \mathrm{ml} . \\
\text { or more })\end{array}$}} & \multirow{2}{*}{\multicolumn{2}{|c|}{$\begin{array}{l}\text { Streptomycin } \\
\text { IC } C_{50} \\
\text { (Resistant to more than } \\
25 \mu \mathrm{g} . / \mathrm{ml} . \text { ) }\end{array}$}} & \multirow{2}{*}{\multicolumn{2}{|c|}{$\begin{array}{l}\text { Tetracycline } \\
I C_{50} \\
(1 \cdot 13 \mu \mathrm{g} . / \mathrm{ml} . \\
\text { or more) }\end{array}$}} & \multirow{2}{*}{\multicolumn{2}{|c|}{$\begin{array}{l}\text { Spiramycin } \\
I C_{50} \\
(0.95 \mu g . / \mathrm{ml} . \\
\text { or more) }\end{array}$}} \\
\hline \multirow[t]{2}{*}{ Definition of lessened sensitivity } & & & & & & & & & \\
\hline & & No. & Per cent. & No. & Per cent. & No. & Per cent. & No. & Per cent. \\
\hline $\begin{array}{l}\text { Thailand } \\
\text { Hong Kong } \\
\text { Taiwan } \\
\text { South Vietnam } \\
\end{array}$ & $\begin{array}{r}12 \\
16 \\
9 \\
6 \\
\end{array}$ & $\begin{array}{r}10 \\
14 \\
9 \\
6\end{array}$ & $\begin{array}{r}83 \cdot 3 \\
87 \cdot 5 \\
100 \cdot 0 \\
100 \cdot 0 \\
\end{array}$ & $\begin{array}{r}10 \\
11 \\
7 \\
6 \\
\end{array}$ & $\begin{array}{r}83 \cdot 3 \\
68 \cdot 8 \\
77 \cdot 8 \\
100 \cdot 0 \\
\end{array}$ & $\begin{array}{r}10 \\
11 \\
8 \\
3 \\
\end{array}$ & $\begin{array}{l}83 \cdot 3 \\
68 \cdot 8 \\
88 \cdot 9 \\
50 \cdot 0\end{array}$ & $\begin{array}{r}10 \\
10 \\
8 \\
6\end{array}$ & $\begin{array}{r}83 \cdot 3 \\
62 \cdot 5 \\
88 \cdot 9 \\
100 \cdot 0\end{array}$ \\
\hline Total & 43 & 39 & $90 \cdot 7$ & 34 & $79 \cdot 1$ & 32 & $74 \cdot 4$ & 34 & $79 \cdot 1$ \\
\hline $\begin{array}{l}\text { Ceylon (1961) } \\
\text { Philippines (1961) }\end{array}$ & $\begin{array}{l}24 \\
20\end{array}$ & $\begin{array}{r}8 \\
20\end{array}$ & $\begin{array}{r}33.5 \\
100 \cdot 0\end{array}$ & $\begin{array}{r}6 \\
13\end{array}$ & $\begin{array}{l}25 \cdot 0 \\
65 \cdot 0\end{array}$ & $\begin{array}{r}6 \\
14\end{array}$ & $\begin{array}{l}25 \cdot 0 \\
70 \cdot 0\end{array}$ & $\begin{array}{l}3 \\
5\end{array}$ & $\begin{array}{l}12 \cdot 5 \\
25 \cdot 0\end{array}$ \\
\hline
\end{tabular}

TABLE XII IC I $_{50}$ cross-susceptibilities of the gonococcus to antibiotics in S.E. Asia (Thailand, Hong Kong, Taiwan, and South Vietnam) (Data from Reyn, 1968*) (See also Fig. 2) (MIC values approximately twice as high)

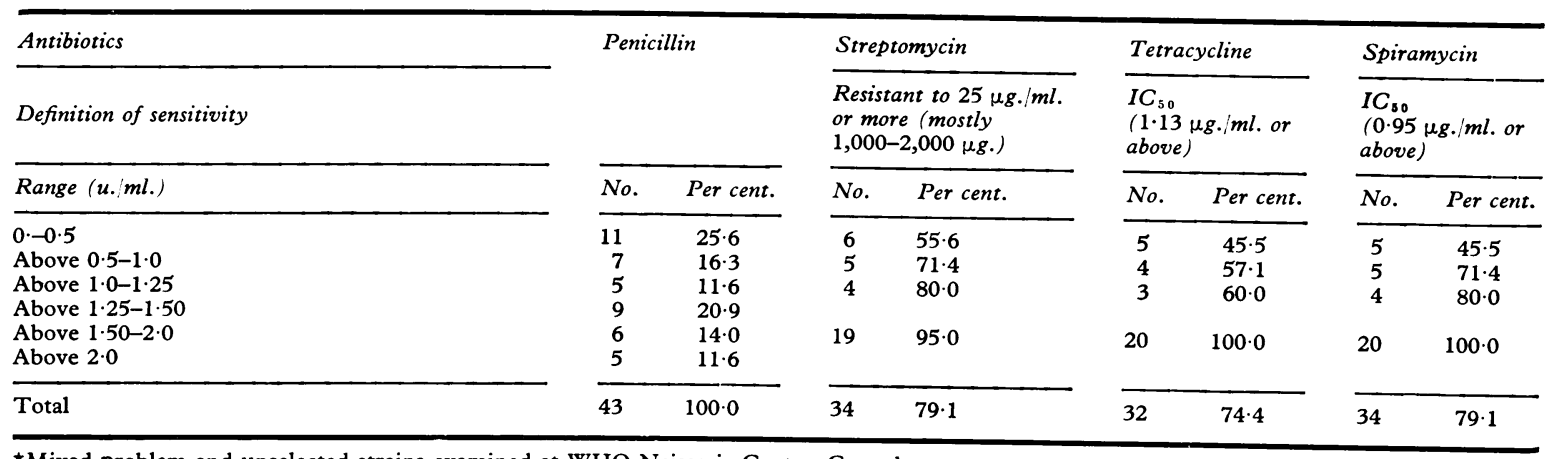

${ }^{\star}$ Mixed problem and unselected strains examined at WHO Neisseria Centre, Copenhagen

Taiwan (Table VIII), 11.1 per cent. had an MIC exceeding 0.5 units $(0.3 \mu \mathrm{g}.) / \mathrm{ml}$. compared with only 0.5 per cent. of similar strains in London (Table II).

Nevertheless, most of the largely unselected strains had an MIC of 1 unit $(0.6 \mu \mathrm{g}$.)/ml. or less (99 per cent. in Australia - Table VII; and 91.7 per cent. in Taiwan - Table VIII), whereas of the problem strains only 25.6 per cent. had an equivalent IC $_{50}$ value (Table XII). Strains of high resistance with an MIC (or equivalent) exceeding 2 units $(1 \cdot 2 \mu \mathrm{g}$.) $/ \mathrm{ml}$. were found in only 1 per cent. or less of largely unselected strains in Australia (Table VII) and Taiwan (Table VIII), but were apparent in no less than 58.1 per cent. of the largely problem strains obtained from a number of areas (Table XII). Some of the latter had IC $_{50}$ values with MIC equivalents of approximately $5 \cdot 6$ units $(3.36 \mu \mathrm{g}$.) $/ \mathrm{ml}$. (Table X).

The strains in Taiwan proved to be more sensitive to ampicillin than to cephaloridine and markedly more so to both of these than to the two penicillinaseresistant penicillins investigated (Table IX).

\section{(b) Other antibiotics and sulphonamides}

A marked degree of cross-resistance was demonstrable in the largely problem strains. Nearly four out of five were completely resistant to streptomycin, nearly three-quarters less sensitive to tetracycline, and four out of five less sensitive to spiramycin. Moreover, the strains least sensitive to penicillin were those more resistant to all three other antibiotics (Table XII; see also Fig. 2, opposite).

Marked discrepancies are apparent in the reports of sensitivities to tetracycline. Some highly resistant strains with an MIC in excess of $50 \mu \mathrm{g} . / \mathrm{ml}$. were reported in the Taiwan series (Table IX), whereas in the mixed strains from this and other areas (Table $\mathrm{X}$ ) the most resistant strain had an MIC equivalent of 


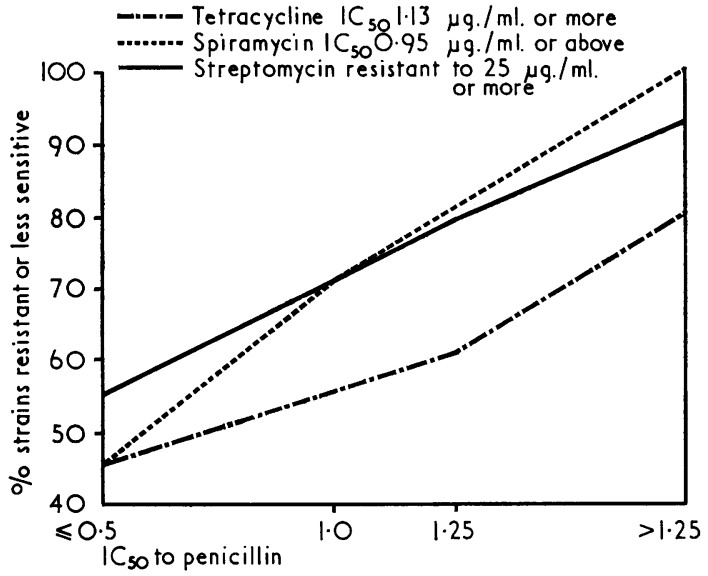

FI G. 2 Relationship of sensitivities to other antibiotics to that to penicillin (Reyn, 1968) (Table XII)

TABLE XIII Sensitivities to tetracycline and spiramycin of mixed strains from Thailand, Hong Kong, Taiwan, and Vietnam by plate dilution method (Data from Reyn, 1968`) (See also Fig. 3) (MIC values approximately twice as high)

\begin{tabular}{|c|c|c|c|c|}
\hline \multirow{2}{*}{$I C_{50}(\mu g . / m l)}$. & \multicolumn{2}{|c|}{ Tetracycline } & \multicolumn{2}{|c|}{ Spiramycin } \\
\hline & No. & Per cent. & No. & Per cent. \\
\hline $\begin{array}{l}0-05 \\
\text { above } 0.5-1 \cdot 0 \\
\text { above } 1 \cdot 0-1.5 \\
\text { above } 1.5-2 \cdot 0 \\
\text { above } 2 \cdot 0-2 \cdot 5 \\
\text { above } 2 \cdot 5-3 \cdot 0 \\
\text { above } 3 \cdot 0-3.5\end{array}$ & $\begin{array}{r}6 \\
5 \\
6 \\
21 \\
4 \\
1 \\
-\end{array}$ & $\begin{array}{r}14 \cdot 0 \\
11 \cdot 6 \\
14 \cdot 0 \\
48 \cdot 8 \\
9 \cdot 3 \\
2 \cdot 3\end{array}$ & $\begin{array}{r}4 \\
8 \\
6 \\
12 \\
8 \\
4 \\
1\end{array}$ & $\begin{array}{r}9 \cdot 3 \\
18 \cdot 6 \\
14 \cdot 0 \\
27 \cdot 9 \\
18 \cdot 6 \\
9 \cdot 3 \\
2 \cdot 3\end{array}$ \\
\hline Total & 43 & $100 \cdot 0$ & 43 & \\
\hline
\end{tabular}

^Examined at WHO Neisseria Centre, Copenhagen only $5 \cdot 2 \mu \mathrm{g} . / \mathrm{ml}$ (Table X). Individual differences in MIC readings were found with different tetracycline preparations (i.e. higher for chlortetracycline - Table IX).

The problem strains tended to be somewhat more resistant to spiramycin, which has had some use in the region by single session therapy (Siboulet and Durel, 1961), than to tetracycline (Table XIII; see also Fig. 3), but they were still sensitive to erythromycin and chloramphenicol (Table XIV), although there is a suggestion that this situation may alter with erythromycin (Table XIV).

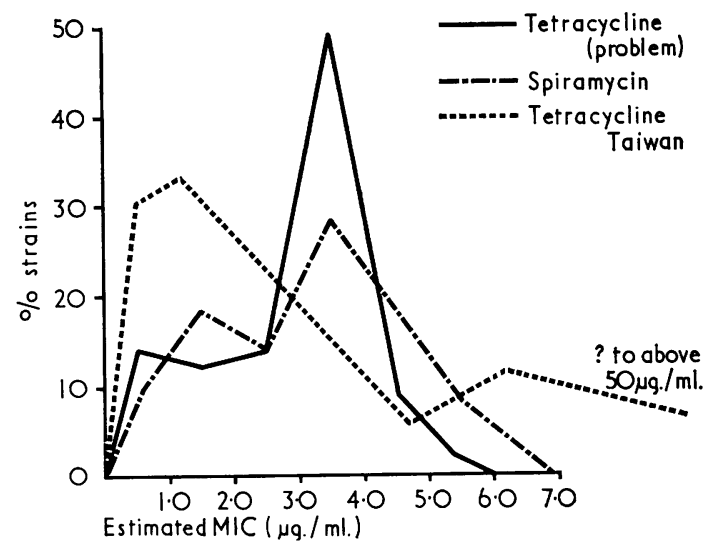

F I G. 3 Distribution of sensitivities to tetracycline and spiramycin in the Far East (Reyn, 1968) (Tables IX and $X I I I)$

A high degree of resistance to sulphonamides has been noted amongst the largely unselected strains from Taiwan (Table IX), while the opposite is true of problem strains from this and other areas (Table XIV). This paradox might be explained by differences in the sulphonamides used.

TABLE XIV Sensitivities to erythromycin, chloramphenicol, and sulphathiazole of mixed strains from Thailand, Hong Kong, and Vietnam by disc method (Data from Reyn, 1968*)

(MIC values approximately twice as high)

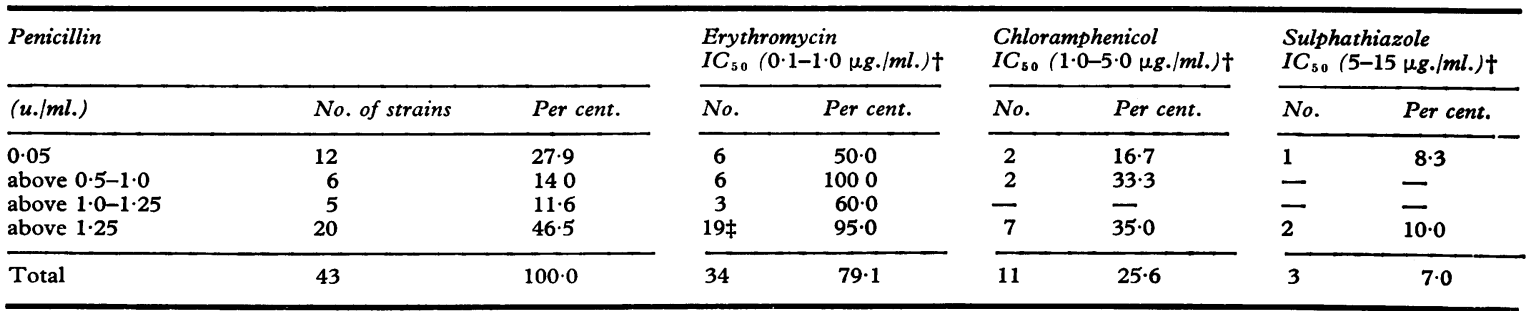

^From the WHO Neisseria Centre, Copehagen.

†Two plus readings by disc method rather than three plus, i.e. not yet defined as 'less sensitive'.

¥One strain exceeded this and was insensitive in excess of $10 \mu \mathrm{g} . / \mathrm{ml}$. 


\section{Penicillin serum levels}

\section{AVAILABLE DATA}

Much of the available information on the serum levels obtained with procaine penicillin concerns either small doses no longer used in the treatment of gonorrhoea (Pulaski and Connell, 1949; Jones and Shooter, 1948; Boger, Crosley, Carfagno, and Bayne, 1952), or doses used for the treatment of syphilis for which lower serum levels were considered necessary (Guthe, Reynolds, Krag, and Willcox, 1953).

Data on serum levels obtained after administering various penicillin preparations are given in Tables XV to XXIV, those mainly concerned with doses relevant to the present-day treatment of gonorrhoea being presented in Tables XVII-XXIV. These indicate that relatively very few subjects have been used for testing and that notable variations have been recorded by different investigators (Tables XV and XVI), and sometimes by the same investigator (Irons, 1950) even on the same subjects (Lucas, 1968) (Table XIX; Fig. 4, opposite).

In general, after the use of crystalline benzyl penicillin G, a high peak is reached rapidly but with small doses the level falls very low after only 4 hours (Table XV). After an injection of procaine penicillin a lower peak is usually apparent within 2 hours with small doses (Table XVII, opposite), but this may be prolonged for 4 hours (occasionally longer) with larger doses (Table XVIII, overleaf); the level is subsequently maintained at approximately 50 per cent. of the peak value until 6 hours have passed (Tables XVII and XVIII). With depot penicillins and mixtures of penicillins containing depot preparations only relatively low levels are obtained by the sixth hour (Table XVII).

Serum levels obtained with penicillins administered orally are shown in Table XXIV. Differences are encountered between the various penicillins and the results are influenced by giving the dose when the patient is fasting.

TABLE XV Duration of penicillinaemia after various penicillin preparations (Data from Bunn, 1959)

\begin{tabular}{|c|c|c|c|c|c|c|}
\hline \multirow[t]{2}{*}{ Penicillin preparation } & \multirow[t]{2}{*}{ Single dose (units) } & \multirow[t]{2}{*}{ Route } & \multirow[t]{2}{*}{ Peak concentration (u./ml.) } & \multicolumn{3}{|c|}{$\begin{array}{l}\text { Serum levels (u./ml.) } \\
\text { (hrs after dose) }\end{array}$} \\
\hline & & & & 4 & 8 & 24 \\
\hline Aqueous & $\begin{array}{l}250,000 \\
500,000\end{array}$ & $\begin{array}{l}\text { Intramuscular } \\
\text { Oral }\end{array}$ & $\begin{array}{l}2 \cdot 5 \\
2 \cdot 0\end{array}$ & $\begin{array}{l}0 \cdot 1 \\
0 \cdot 1\end{array}$ & $\begin{array}{l}0.02 \\
0.03\end{array}$ & - \\
\hline Procaine & $\begin{array}{l}300,000 \\
600,000 \\
\end{array}$ & $\begin{array}{l}\text { Intramuscular } \\
\text { Intramuscular }\end{array}$ & $\begin{array}{l}0.6 \\
0.75-1.0\end{array}$ & $\begin{array}{l}0 \cdot 1 \\
0 \cdot 15\end{array}$ & $\begin{array}{l}0.05 \\
0.06\end{array}$ & $\begin{array}{l}0.02 \\
0.02\end{array}$ \\
\hline Procaine in oil & $600,000^{\star}$ & Intramuscular & $0.6-0.75$ & $0 \cdot 12$ & 0.06 & 0.03 \\
\hline Benzathine & $\begin{array}{l}300,000 \dagger \\
1,200,000 \ddagger\end{array}$ & $\begin{array}{l}\text { Intramuscular } \\
\text { Intramuscular }\end{array}$ & $\begin{array}{l}0.4 \\
0.5\end{array}$ & $\begin{array}{l}0.05 \\
0.05\end{array}$ & $\begin{array}{l}0.05 \\
0.05\end{array}$ & $\begin{array}{l}0.03 \\
0.03\end{array}$ \\
\hline
\end{tabular}

Peak levels usually obtainable within 2 hours.

*Levels between 0.02 and 0.03 units persist for 3-4 days.

†Levels between 0.02 and 0.025 units persist for 6-10 days.

¥Levels between 0.02 and 0.025 units persist for 14-21 days.

( 2 units $=1.2 \mu \mathrm{g}$.)

TABLE XVI Wide ranges of penicillinaemia (u./ml.) after 600,000 units procaine penicillin

\begin{tabular}{|c|c|c|c|c|c|c|}
\hline \multirow{2}{*}{ Author } & \multirow{2}{*}{ Date } & \multirow{2}{*}{ No. of subjects tested } & \multicolumn{4}{|c|}{ Hours after injection } \\
\hline & & & 1 & 6 & 12 & 24 \\
\hline Griffith and Peck & 1958 & 25 & $\begin{array}{l}0 \cdot 60-3 \cdot 20 \\
(\text { mean } 3 \cdot 10)\end{array}$ & $\begin{array}{l}0 \cdot 22-1 \cdot 15 \\
(\text { mean } 0 \cdot 70)\end{array}$ & $\begin{array}{l}\text { below } \\
0 \cdot 02-0 \cdot 60 \\
(\text { mean } 0 \cdot 20)\end{array}$ & $\begin{array}{l}\text { below } \\
0.02-0.22 \\
\text { (mean } 0.03 \text { ) }\end{array}$ \\
\hline White and others* & 1956 & 10 & $\begin{array}{l}0.54-2.77 \\
\text { (mean } 1.82 \text { ) }\end{array}$ & $\begin{array}{l}0.61-1.87 \\
\text { (mean } 1.04 \text { ) }\end{array}$ & 一 & - \\
\hline Cohen & 1950 & 2 & $\begin{array}{l}2 \cdot 0-2 \cdot 0 \\
(\text { mean } 2 \cdot 0)\end{array}$ & $t$ & $\begin{array}{l}0.5-0.5 \\
(\text { mean } 0.5)\end{array}$ & $\begin{array}{l}0.08-0.125 \\
(\text { mean } 0.1)\end{array}$ \\
\hline
\end{tabular}

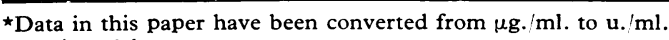

t1 unit at 8 hrs. 

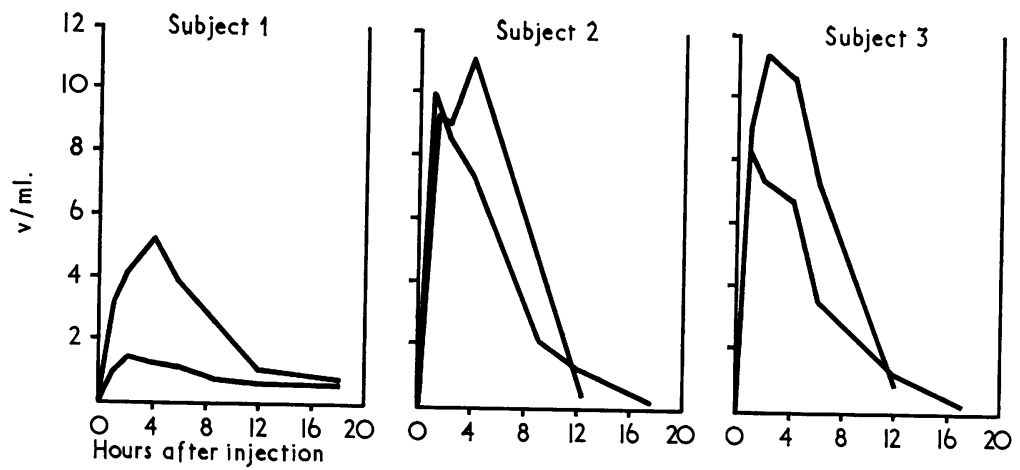

FIG. 4 Reproducibility of serum level after $2.4 \mathrm{~m} . u$. procaine penicillin in three subjects (Lucas, 1968) (Table XIX, overleaf)

TABLE XVII Mean serum levels (u./ml.) after single injections of various penicillin preparations ( $\mu \mathrm{g} . / \mathrm{ml}).(1.2 \mu \mathrm{g}$. equals 2 units)

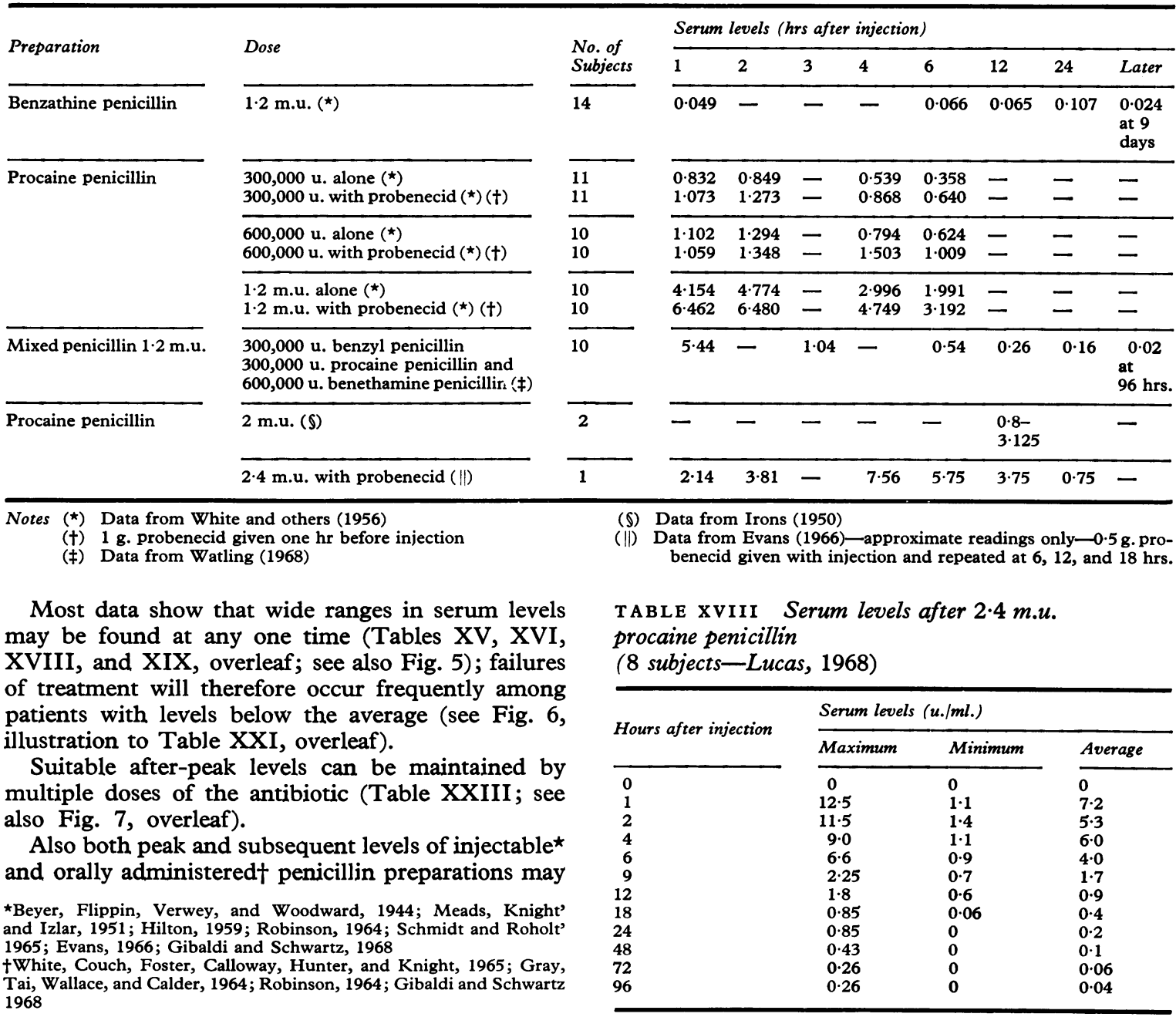


TABLE XIX Repeated serum levels (u./ml.) after 2.4 m.u. procaine penicillin given on two occasions to each of three patients

(Lucas, 1968) (See also Fig. 4)

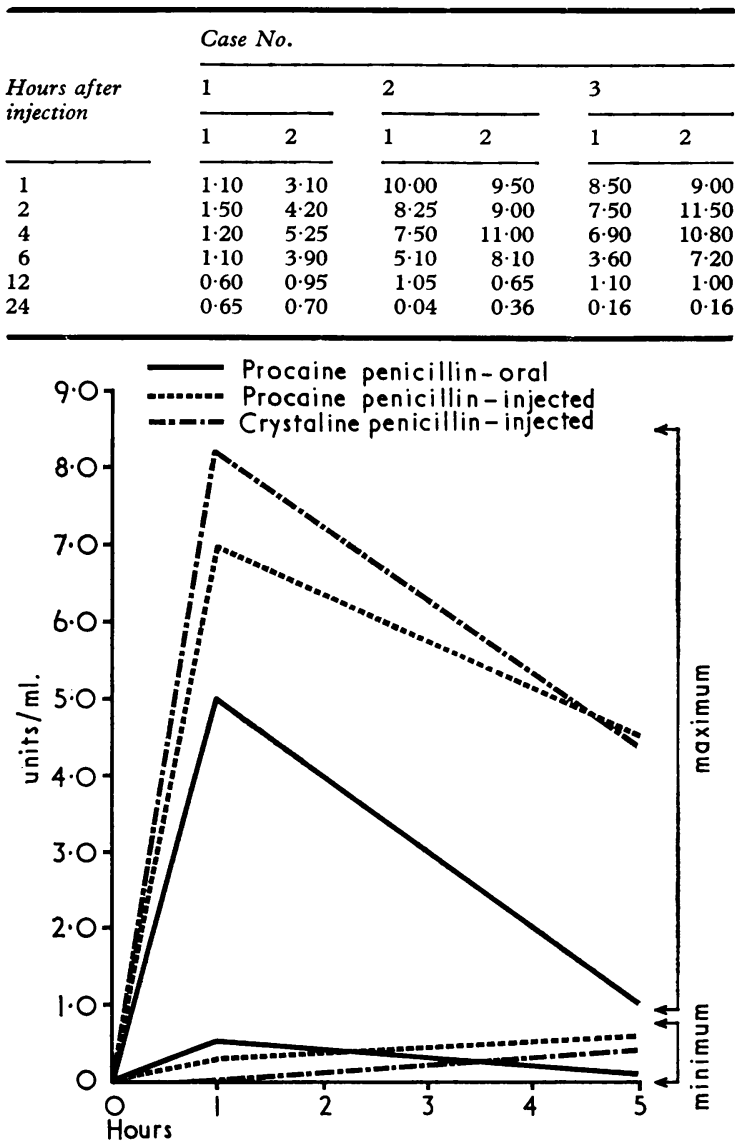

FIG. 5 Maximum and minimum serum levels after $500,000 u$. of three penicillins (Wormer, Martin, Nichols, Heilman, and Rose, 1955)

TABLE XX Serum levels after 3 m.u. procaine penicillin

(Knudsen and Perdrup, 1963)

\begin{tabular}{|c|c|c|c|}
\hline \multirow{2}{*}{ Hours after injection } & \multicolumn{3}{|c|}{ Serum levels (u./ml.) } \\
\hline & Maximum & Minimum & Mean \\
\hline 0 & 0 & 0 & 0 \\
\hline$\frac{1}{2}$ & 8.65 & 1.55 & $5 \cdot 31$ \\
\hline 1 & 14.85 & $3 \cdot 70$ & $7 \cdot 96$ \\
\hline 2 & $19 \cdot 50$ & $4 \cdot 70$ & 9.92 \\
\hline 4 & $19 \cdot 50$ & 4.60 & $9 \cdot 25$ \\
\hline 8 & 6.64 & 0.88 & 4.89 \\
\hline 24 & $1 \cdot 60$ & 0 & 0.51 \\
\hline
\end{tabular}

be considerably enhanced by the use of probenecid (Tables XVII, XXII, XXIII, XXIV, opposite and
TABLE XXI Percentage patients failing to reach certain blood levels after single injections of $1.2 \mathrm{~m} . u$. procaine penicillin

(Calculated on data on eleven subjects from White and others, 1956) (See also Fig. 6)

\begin{tabular}{|c|c|c|c|c|c|}
\hline \multirow{2}{*}{ Units/ml. } & \multirow{2}{*}{$\mu g \cdot / m l}$. & \multicolumn{4}{|c|}{ Hours after injection } \\
\hline & & $i$ & 2 & 4 & 6 \\
\hline $\begin{array}{l}0 \\
0.5 \\
1.0 \\
1 \cdot 25 \\
1.50 \\
2.0 \\
2.5 \\
3.0 \\
3.5 \\
4.0 \\
5 \cdot 0 \\
6.0 \\
7 \cdot 0 \\
8.0\end{array}$ & $\begin{array}{l}0 \\
0.3 \\
0.6 \\
0 \cdot 75 \\
0.9 \\
1 \cdot 2 \\
1 \cdot 5 \\
1 \cdot 8 \\
2 \cdot 1 \\
2 \cdot 4 \\
3 \cdot 0 \\
3 \cdot 6 \\
4 \cdot 2 \\
4 \cdot 8\end{array}$ & $\begin{array}{c}0 \\
0 \\
0 \\
0 \\
18 \cdot 2 \\
18 \cdot 2 \\
27 \cdot 3 \\
27 \cdot 3 \\
45 \cdot 5 \\
45 \cdot 5 \\
45 \cdot 5 \\
45 \cdot 5 \\
54 \cdot 5 \\
54 \cdot 5\end{array}$ & $\begin{array}{c}0 \\
0 \\
0 \\
0 \\
0 \\
18 \cdot 2 \\
27 \cdot 3 \\
36 \cdot 4 \\
36 \cdot 4 \\
36 \cdot 4 \\
36 \cdot 4 \\
45 \cdot 5 \\
45 \cdot 5 \\
54 \cdot 5\end{array}$ & $\begin{array}{l}0 \\
0 \\
9 \cdot 1 \\
9 \cdot 1 \\
18 \cdot 2 \\
27 \cdot 3 \\
27 \cdot 3 \\
27 \cdot 3 \\
36 \cdot 4 \\
36 \cdot 4 \\
45 \cdot 5 \\
45 \cdot 5 \\
72 \cdot 7 \\
90 \cdot 9\end{array}$ & $\begin{array}{l}0 \\
0 \\
18 \cdot 2 \\
18 \cdot 2 \\
27 \cdot 3 \\
27 \cdot 3 \\
45 \cdot 5 \\
45 \cdot 5 \\
54 \cdot 5 \\
54 \cdot 5 \\
54 \cdot 5 \\
100 \cdot 0 \\
100 \cdot 0 \\
100 \cdot 0\end{array}$ \\
\hline $\begin{array}{l}\text { Greater than } \\
8.0\end{array}$ & $\begin{array}{l}\text { Greater than } \\
4.8\end{array}$ & $45 \cdot 5$ & $45 \cdot 5$ & 0 & 0 \\
\hline Mean & $\begin{array}{l}\text { Micro- } \\
\text { grammes } \\
\text { Units }\end{array}$ & $\begin{array}{l}4 \cdot 154 \\
6 \cdot 9\end{array}$ & $\begin{array}{l}4 \cdot 774 \\
7 \cdot 9\end{array}$ & $\begin{array}{l}2.996 \\
5.0\end{array}$ & $\begin{array}{l}1.991 \\
3.3\end{array}$ \\
\hline
\end{tabular}

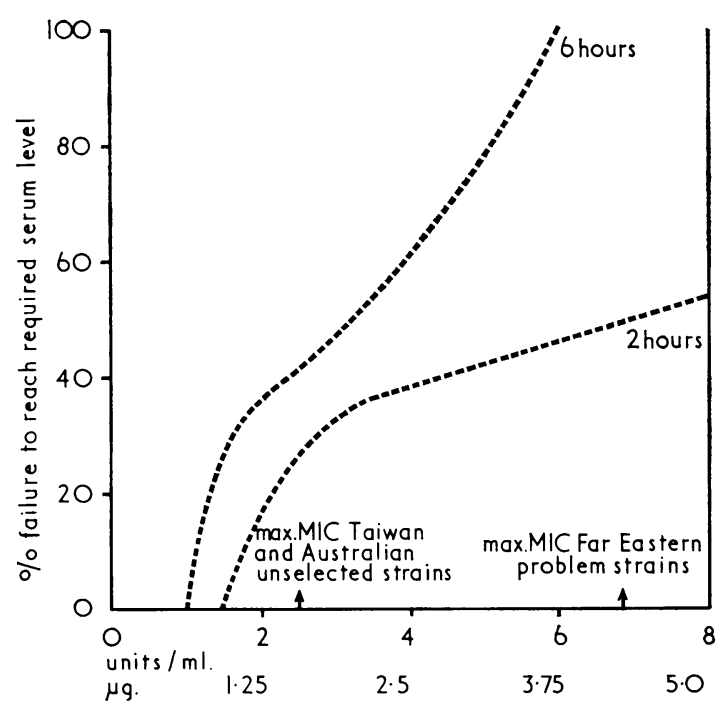

FI G. 6 Percentage failing to reach required serum levels after 1.2 m.u. procaine penicillin (Table XXI)

overleaf; see also Figs. 7, 8, 9). This may be given either in $0.5-\mathrm{g}$. doses 6 -hrly or in $1-\mathrm{g}$. doses twice daily. When the latter dosage has been used a twofold enhancement of the penicillin level has been claimed, and when $3 \mathrm{~g}$. have been given ( $1 \mathrm{~g}$. 8-hrly) the increase has been five-fold or more (Meads, Knight, and Izlar, 1951). 
TABLE XXII Serum levels after $5 \mathrm{m.u}$. benzyl penicillin with and without $1 \mathrm{~g}$. probenecid $30 \mathrm{~min}$. before injection (Schmidt and Roholt, 1965)

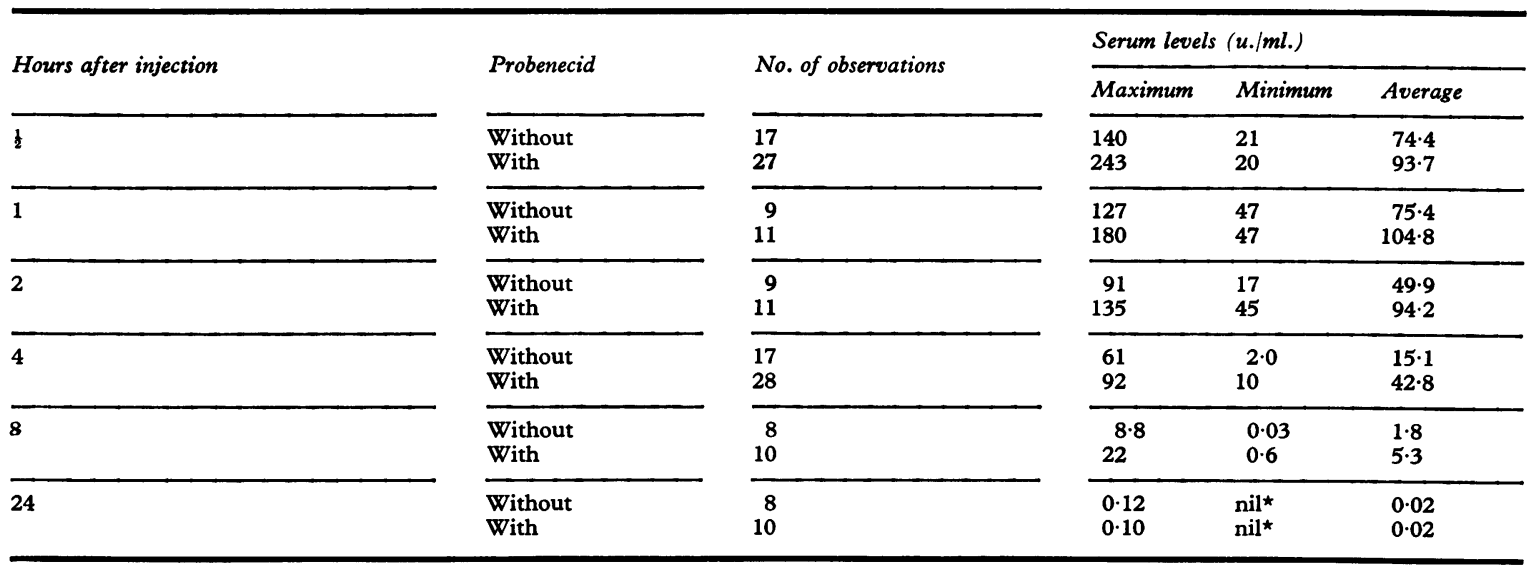

^Readings of $0.02 \mathrm{u} . / \mathrm{ml}$. or less taken as zero.

TABLE XXIII Mean serum levels after multiple doses of penicillin ( $\mu g . / m l$.

(Data from White and others, 1956) (See also Fig. 7)

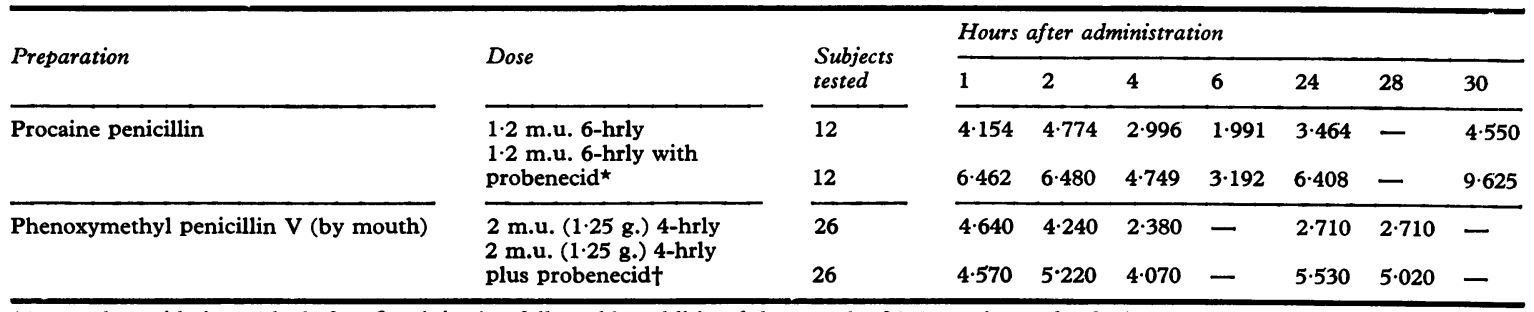

$\star 1 \mathrm{~g}$. probenecid given $1 \mathrm{hr}$ before first injection followed by additional doses each of $0.5 \mathrm{~g}$. at intervals of $6 \mathrm{hrs}$.

$+1 \mathrm{~g}$. probenecid given $1 \mathrm{hr}$ before first dose followed by two further doses of $1 \mathrm{~g}$. at 8-hr intervals.

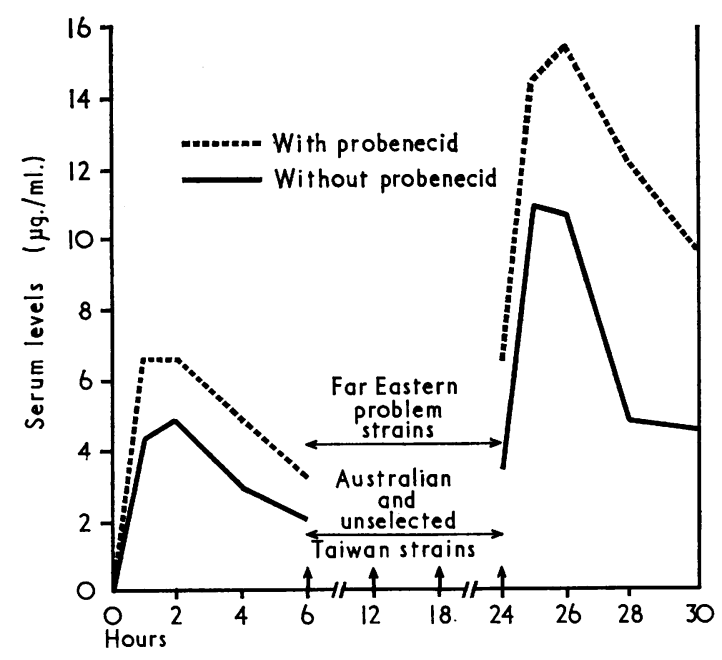

FI G. 7 Serum levels after $1 \cdot 2$ m.u. procaine penicillin with and without probenecid (White and others, 1956) (Table $X X I I I)$
RELATION OF SERUM LEVELS TO TREATMENT FAILURE A decade ago in London it was considered that the 'ideal' penicillin therapy for gonorrhoea was a regime which would provide a minimum serum level of 1 unit $(0.6 \mu \mathrm{g}$.) $/ \mathrm{ml}$. for 24 hours with a rapid cut-off (Curtis and Wilkinson, 1958). This has been demonstrated by using a single injection of 2.4 mega units procaine penicillin with repeated doses of probenecid, the cut-off being enforced by an injection of 800,000 units penicillinase (Evans, 1966). It is probable that a shorter period would suffice, at least in male cases; cultures have been shown to become negative usually within 2 to 9 hours after treatment with penicillin (Knudsen and Perdrup, 1963; Holmes and others, 1967a) and within 12 hours after tetracycline (Holmes and others, 1967a).

This theoretical 'ideal' is probably still sufficient for most of the relatively insensitive gonococci circulating in London (Table II), but in Taiwan a serum level of at least 2 units $(1 \cdot 2 \mu \mathrm{g}$. $) / \mathrm{ml}$. penicillin G (Table VIII), or $3.2 \mu \mathrm{g} . / \mathrm{ml}$. ampicillin (Table IX), is required for unselected strains, while to deal 
TABLE XXIV Serum levels following single oral doses of various penicillins with and without probenecid ( $\mu$ g./ml.) (See also Fig. 9)

\begin{tabular}{|c|c|c|c|c|c|c|}
\hline Preparation & Dose & $\begin{array}{l}\text { Subjects } \\
\text { tested }\end{array}$ & \multicolumn{4}{|c|}{ Hours after dose } \\
\hline \multirow[t]{2}{*}{ Phenoxymethyl penicillin $\mathrm{V}$} & 2 m.u. (1.2 g.) & 26 & $4 \cdot 640$ & $4 \cdot 240$ & $2 \cdot 380$ & - \\
\hline & $\begin{array}{l}2 \text { m.u. ( } 1.2 \mathrm{~g} \text {.) plus } 1 \mathrm{~g} \text {. probenecid } 1 \mathrm{hr} \text { before penicillin } \\
\text { (White and others, 1956) }\end{array}$ & 26 & $4 \cdot 570$ & $5 \cdot 220$ & $4 \cdot 070$ & - \\
\hline \multirow[t]{2}{*}{ Phenethicillin } & $1 \mathrm{~g}$. & 5 & $9 \cdot 2$ & $3 \cdot 0$ & 1.9 & $0 \cdot 4$ \\
\hline & $1 \mathrm{~g}$. plus $0.5 \mathrm{~g}$. probenecid in fasting subjects (Robinson, 1964) & 5 & $22 \cdot 9$ & $12 \cdot 5$ & $4 \cdot 4$ & $1 \cdot 3$ \\
\hline \multirow[t]{2}{*}{ Ampicillin } & $0.5 \mathrm{~g}$ & 6 & $2 \cdot 5$ & $3 \cdot 2$ & 1.9 & 0.5 \\
\hline & $\begin{array}{l}0.5 \mathrm{~g} \text {. plus two previous doses of } 0.5 \mathrm{~g} \text {. probenecid in fasting } \\
\text { subjects (Robinson, 1964) }\end{array}$ & 6 & $2 \cdot 4$ & $4 \cdot 7$ & 3.6 & 0.9 \\
\hline
\end{tabular}

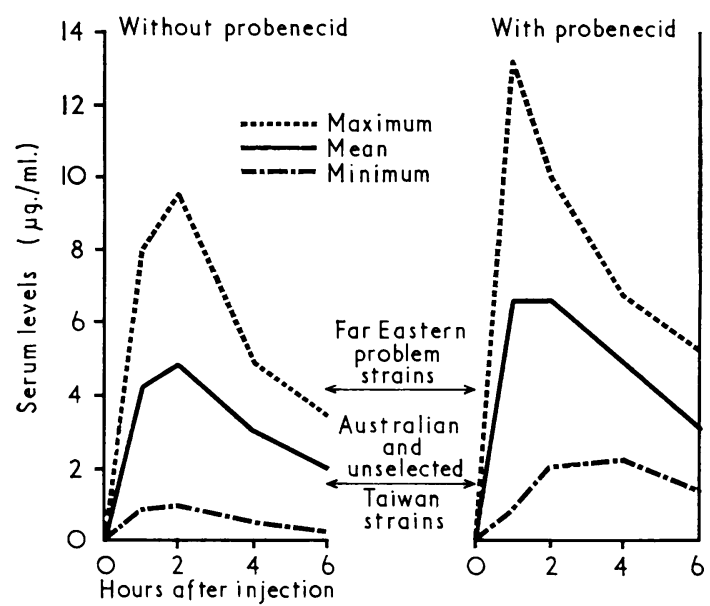

FIG. 8 Maximum, minimum, and mean serum levels after $1.2 \mathrm{~m} . u$. procaine penicillin with and without probenecid in 11 subjects

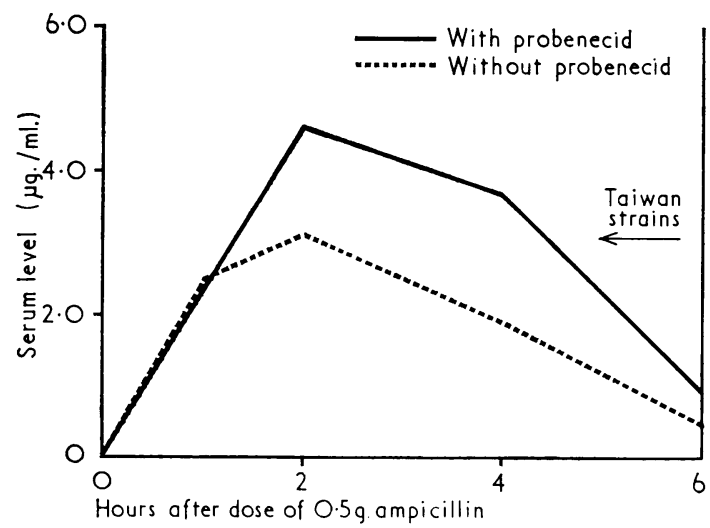

FI G. 9 Serum levels after $0.5 \mathrm{~g}$. ampicillin with and without probenecid (Robinson, 1964) (Table XXIV) effectively with all problem strains (Table $\mathrm{X}$ ) a level in excess of 5.6 units $(3.36 \mu \mathrm{g}.) / \mathrm{ml}$. is apparently necessary, 2 units $(1 \cdot 2 \mu \mathrm{g}$. $) / \mathrm{ml}$. sufficing for only 41.9 per cent. of them (Table XII). No information for these strains is available concerning ampicillin.

In any event serum levels higher than those indicated by tests in vitro are needed to lessen the probability of treatment failures in patients who do not achieve the mean serum level. Little is known of antibiotic levels required in the relevant tissues in gonorrhoea, but in uncomplicated cases these are assumed to be similar to the serum level. Nevertheless, wide variations of levels of penicillin and other antibiotics are found in various tissues (Table XXV) and body fluids. Tests with different antibiotics in dogs have shown marked differences between the serum concentrations and those of the prostatic fluid (Table XXVI, opposite). Another unknown factor is the effect, if any, of the very high urine levels of penicillin which follow even small doses (Table XXVII, opposite); these may contribute in part to better therapeutic results in the male.

TABLE XXV Varying penicillin concentrations in different tissues after injection of 300,000 $u$. crystalline potassium penicillin G (Bunn, 1959)

\begin{tabular}{|c|c|c|}
\hline Tissue & $\begin{array}{l}\text { After } 1 \mathrm{hr} \\
(\mathrm{u} . / \mathrm{ml} \text {. or } \mathrm{g.} .)\end{array}$ & $\begin{array}{l}\text { After } 3 \text { hrs } \\
\text { (u./ml. or g.) }\end{array}$ \\
\hline Kidney & 15 & trace \\
\hline Intestine & 8 & \\
\hline Lung & 8 & trace \\
\hline Buccal mucosa & 6 & 0 \\
\hline Skin & 5 & trace \\
\hline Liver & 4 & trace \\
\hline Heart & 2 & trace \\
\hline Muscle & 1.5 & trace \\
\hline \multicolumn{3}{|l|}{ Central nervous } \\
\hline system tissues & 0 -trace & $\mathbf{0}$ \\
\hline Bone marrow & 0 & $\mathbf{0}$ \\
\hline
\end{tabular}


TABLE XXVI Correlation between antibiotic levels in plasma, prostatic fluid, and urine in dogs (Data from Winningham, Nemoy, and Stamey, 1968)

\begin{tabular}{|c|c|c|c|c|}
\hline \multirow{2}{*}{ Antibiotic (various doses) } & \multirow{2}{*}{ No. of tests } & \multicolumn{3}{|c|}{ Simultaneous estimations of } \\
\hline & & Plasma ( $\mu g . / m l)$. & Prostatic fluid ( $\mu \mathrm{g} . / \mathrm{ml})$. & Urine ( $\mu \mathrm{g} . / \mathrm{ml})$. \\
\hline Cephalothin & 1 & 63 & Less than 0.4 & 1,083 \\
\hline Ampicillin & 1 & 54 & Less than 0.2 & 5,050 \\
\hline Oxytetracycline & 1 & 10 & Less than $2 \cdot 0$ & 230 \\
\hline Kanamycin & 2 & $32-41$ & Less than $2 \cdot 0$ & 7,250 -more than 9,000 \\
\hline Erythromycin & 3 & $5-20$ & $8-26$ & $125-675$ \\
\hline Oleandomycin & 2 & $12-14$ & $29-39$ & $700-8,600$ \\
\hline
\end{tabular}

TABLE XXVII Serum and urine ranges (u./ml.) after 4,000 u./kg. body weight of procaine penicillin*7 subjects (Pulaski and Connell, 1949)

\begin{tabular}{|c|c|c|c|c|c|c|c|c|c|}
\hline \multirow{2}{*}{ Range } & \multicolumn{9}{|c|}{ Hours after injection } \\
\hline & 1 & 3 & 6 & 12 & 18 & 24 & 30 & 36 & 48 \\
\hline $\begin{array}{r}\text { Serum Max. } \\
\text { Min. }\end{array}$ & $\begin{array}{l}2.5 \\
0.31\end{array}$ & $\begin{array}{l}1.25 \\
0.31\end{array}$ & $\begin{array}{l}0.62 \\
0.31\end{array}$ & $\begin{array}{l}0.31 \\
0.04\end{array}$ & $\begin{array}{l}0.46 \\
0.04\end{array}$ & $\begin{array}{l}0.08 \\
0.04\end{array}$ & 二 & $\begin{array}{l}0 \\
0\end{array}$ & $\begin{array}{l}\mathbf{0} \\
\mathbf{0}\end{array}$ \\
\hline $\begin{array}{r}\text { Urine Max. } \\
\text { Min. }\end{array}$ & $\begin{array}{r}200 \cdot 0 \\
72 \cdot 0\end{array}$ & - & $\begin{array}{l}200 \cdot 0 \\
160 \cdot 0\end{array}$ & $\begin{array}{r}200 \cdot 0 \\
50 \cdot 0\end{array}$ & $\begin{array}{r}200 \cdot 0 \\
19 \cdot 5\end{array}$ & $\begin{array}{r}76 \cdot 0 \\
0.6\end{array}$ & $\begin{array}{r}23.0 \\
0.6\end{array}$ & $\begin{array}{r}23 \cdot 0 \\
0 \cdot 4\end{array}$ & $\begin{array}{l}3 \cdot 4 \\
0.4\end{array}$ \\
\hline
\end{tabular}

$\star$ i.e. $300,000 \mathrm{u}$. for a patient weighing $75 \mathrm{~kg}$.

The whole matter is further complicated by protein-binding in both blood and tissues, whereby the antibiotic is held in a reversible state, partly attached to proteins when it is inert and partly free and active, the bound fraction being liberated as the free fraction is eliminated (Rolinson, 1964; Knudsen, 1964; Bond, 1964; Quinn, 1964).

The various penicillins differ considerably in the percentages rendered temporarily inactive by protein binding. Only approximately one-fifth of ampicillin is bound in this way compared with from two-thirds to four-fifths of benzyl penicillin G, phenethicillin, and phenoxymethyl penicillin (Table XXVIII). The effects of protein-binding may influence the validity of the comparative MIC values of some antibotics and of penicillin serum level estimations according to the techniques used (Knudsen, 1964).

TABLE XXVIII Percentage binding of different penicillins in human serum according to three different authors

\begin{tabular}{|c|c|c|c|}
\hline Penicillin & $\begin{array}{l}\text { Quinn } \\
\text { (1964) }\end{array}$ & $\begin{array}{l}\text { Rolinson } \\
\text { (1964) }\end{array}$ & $\begin{array}{l}\text { Bond } \\
\text { (1964) }\end{array}$ \\
\hline $\begin{array}{l}\text { Ampicillin } \\
\text { Methicillin } \\
\text { Benzyl penicillin } G \\
\text { Cephalothin } \\
\text { Phenethicillin } \\
\text { Phenoxymethyl penicillin } \\
\text { Nafcillin } \\
\text { Oxacillin } \\
\text { Propicillin } \\
\text { Phenbenicillin }\end{array}$ & $\begin{array}{l}21 \\
35 \\
68 \\
70 \\
71 \\
75 \\
84 \\
88 \\
88 \\
\end{array}$ & $\begin{array}{l}18 \\
49 \cdot 3 \\
= \\
\overline{7} \\
\overline{79 \cdot 7} \\
\frac{93 \cdot 1}{-}\end{array}$ & $\begin{array}{l}\bar{Z} \\
\bar{Z} \\
\overline{75 \cdot 2} \\
80 \cdot 1 \\
\overline{-} \\
\overline{89 \cdot 3} \\
97 \cdot 2\end{array}$ \\
\hline
\end{tabular}

IMPLICATIONS OF THE DATA

The data presented indicate that, to provide serum levels high enough to overcome all reported Far Eastern strains with preparations of penicillin G, multiple injections of large doses or repeated high oral doses combined with probenecid are required (Table XXII). Nevertheless, levels sufficient to combat the general range of unselected strains should be achievable at least in males either with single injections of a minimum of 2.4 mega units procaine penicillin plus probenecid (Tables VI, XVII), or with 5 mega units benzyl penicillin $G$ plus probenecid (Table XXII). The first approach requires the sacrifice of single-injection methods; this entails a return to hospitalization, or the provision of antibiotic tablets to be taken without supervision with all its attendant disadvantages. The second, more realistic, approach provides better opportunities for the treatment of large numbers of patients.

\section{Tetracycline serum levels}

Of the well-known analogues of tetracycline, chlortetracycline has given the highest (but least sustained) serum levels (Kunin, Dornbush, and Finland, 1959; Ho and Chang, 1967) and demethylchlortetracycline the most sustained (Kunin and others, 1959). Tetracycline gives higher levels than oxytetracycline (Kunin and others, 1959), and the phosphate complex of tetracycline produces significantly higher levels than tetracycline hydrochloride (Olon and Holvey, 
TABLE XXIX Mean serum levels ( $\mu g . / m l$.$) with three tetracyclines taken twice daily$ (Olon and Holvey, 1968)

\begin{tabular}{|c|c|c|c|c|c|c|c|c|c|c|c|}
\hline Preparation & Dose & \multicolumn{10}{|c|}{ Hours after first dose } \\
\hline Tetracycline phosphate complex & $\begin{array}{l}500 \mathrm{mg} . \\
\text { twice daily }\end{array}$ & $1 \cdot 49$ & $1 \cdot 30$ & $1 \cdot 06$ & 0.83 & 0.64 & $1 \cdot 45$ & $3 \cdot 42$ & $3 \cdot 78$ & $3 \cdot 48$ & $0 \cdot 22$ \\
\hline Demethylchlortetracycline & $\begin{array}{l}300 \mathrm{mg} . \\
\text { twice daily }\end{array}$ & $0 \cdot 70$ & $0 \cdot 72$ & 0.68 & 0.57 & 0.39 & 0.93 & 1.74 & $2 \cdot 00$ & $2 \cdot 20$ & $0 \cdot 28$ \\
\hline
\end{tabular}

«No drug after $96 \mathrm{hrs}$.

TABLE XXX Serum concentrations ( $\mu \mathrm{g} . / \mathrm{ml}$.) after single oral doses of $500 \mathrm{mg}$. of two tetracyclines (Shidlovsky and others, 1958*) (See also Fig. 10)

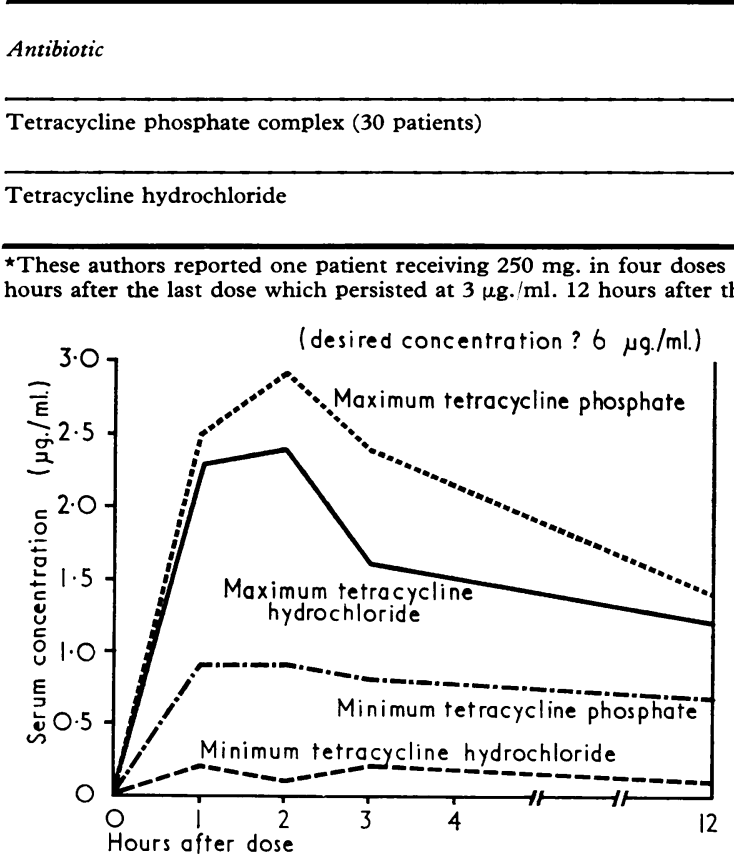

FI G. 10 Maximum and minimum serum levels after $500 \mathrm{mg}$. of two tetracyclines (Table $X X X$ )

1968; Shidlovsky, Prigot, Maynard, Felix, and HjeltHarvey, 1958: Tables XXIX and XXX; see also Fig. 10) and also than demethylchlortetracycline and methacycline (Table XXVI). Both demethylchlortetracycline and chlortetracycline are bound to plasma to about the same extent ( 41 to 47 per cent.), which is about double the value ( 20 to 24 per cent.) for oxytetracycline and tetracycline (Kunin and others, 1959).

Whether tetracycline is given as $250 \mathrm{mg}$. 6-hrly or as $500 \mathrm{mg}$. 12-hrly, approximately 48 hours are required to reach a serum level approaching 4 to 5

\begin{tabular}{|c|c|c|c|c|}
\hline & \multicolumn{4}{|c|}{ Hours after medication } \\
\hline & 1 & 2 & 3 & 12 \\
\hline $\begin{array}{l}\text { Average } \\
\text { Range }\end{array}$ & $\begin{array}{l}1.49 \\
(0.90-2.5)\end{array}$ & $\begin{array}{l}1 \cdot 88 \\
(0 \cdot 93-2 \cdot 85)\end{array}$ & $\begin{array}{l}1.56 \\
(0.75-2 \cdot 40)\end{array}$ & $\begin{array}{l}0.72 \\
(0 \cdot 71-1 \cdot 44)\end{array}$ \\
\hline $\begin{array}{l}\text { Average } \\
\text { Range }\end{array}$ & $\begin{array}{l}0 \cdot 79 \\
(0 \cdot 20-2 \cdot 3)\end{array}$ & $\begin{array}{l}0.86 \\
(0 \cdot 12-2 \cdot 37)\end{array}$ & $\begin{array}{l}0.80 \\
(0.23-1.59)\end{array}$ & $\begin{array}{l}0.47 \\
(0 \cdot 12-1 \cdot 24)\end{array}$ \\
\hline
\end{tabular}

Average

Range

Range $\mu \mathrm{g} . / \mathrm{ml}$. (Shidlovsky and others, 1958), the higher figure being required to combat most of the problem strains of the Far East (Table XIII). Increasing the dose above $1 \mathrm{~g}$. daily does not appear to produce significantly higher blood levels (Herrell, Heilman, and Wellman, 1950; Welch, 1950), although levels up to 9 to $11 \mu \mathrm{g} . / \mathrm{ml}$. can be achieved with mixed tetracycline preparations.

The blood level 'curve' is a plateau, having a slow rise and a slower fall. The height and duration of this plateau is dependent on continued absorption or injection, biliary excretion, and re-absorption, and on protein-binding in the plasma (Barker, 1968).

To obtain a serum level of $25 \mu \mathrm{g} . / \mathrm{ml}$. even temporarily with tetracyclines, intravenous administration is necessary. Using rolitetracycline $350 \mathrm{mg}$. in this way, a peak serum level of $30 \mu \mathrm{g} . / \mathrm{ml}$. is rapidly reached, but this falls quickly to $20 \mu \mathrm{g}$. $/ \mathrm{ml}$. within 10 minutes and then to about $1 \mu \mathrm{g} . / \mathrm{ml}$. in 24 hours (Shidlovsky and others, 1958; Wagner, 1964). It has been suggested that a larger dose of rolitetracycline (700 mg.) could be given intravenously, and that this could be combined with $500 \mathrm{mg}$. tetracycline phosphate twice daily for 2 days. This dosage has been considered to be within the limits of safety, although patients with hepatic dysfunction should be excluded (Barker, 1968). Even if this level could be properly maintained, it would still not reach the MIC of all the strains reported in Taiwan (Ho and Chang, 1967 - Table IX). 


\section{Available treatments for gonorrhoea (Appendix I)}

Many antibiotics have been found effective against gonorrhoea and new ones are being developed. The clinical experience obtained with penicillins by injection are summarized in Table XXXI, with orally administered and other penicillins in Table XXXII, with other injectable antibiotics in Table XXXIII, and with other orally administered antibiotics in Table XXXIV. It is emphasized that the efficacy of one treatment in any one country at any one time does not by any means necessarily apply to another treatment in the same country in a different year. Also most of the published information refers to male patients. Females need more prolonged and intensive treatment (Shapiro and Lentz, 1967), given for approximately double the time required by males.

\section{INJECTABLE PENICILlINS (Table XXXI)}

Even in areas with highly resistant gonococci, satisfactory cures can still be obtained with single injections of crystalline benzyl penicillin $G$ in high doses with probenecid, while repeated injections of this or of procaine penicillin can be expected to produce levels in excess of the MIC of the least sensitive strains if given in sufficient amounts and with sufficient frequency.

Single injections of 2.4 mega units procaine penicillin by themselves are now inadequate in the Far East (Table VI). Higher doses of procaine penicillin (i.e. 4.8 mega units) have been used for single session treatment in the USA (Lucas, Price, Thayer, and Schroeter, 1967; Shapiro and Lentz, 1967), but unless this preparation can be further concentrated a dose of this size probably represents the limit of the amount that can be given in a single injection (Shapiro and Lentz, 1967) if it does not exceed it (Holmes and others, 1967a); even so 14 per cent. of failures have been obtained with this technique. The limit of usefulness of procaine penicillin is thus being reached because of the bulk of the injection and not because of toxicity; apart from allergic effects and occasional acute psychotic reactions blamed on its procaine moiety resulting from accidental injection into a vein (Utley, Lucas, and Billings, 1966), there have been few reports of toxic reactions in spite of the relatively large proportion of procaine in the compound (Knudsen and Perdrup, 1963). Large single doses of procaine penicillin fortified by benzyl penicillin, a mixture which can contain more units $/ \mathrm{ml}$. than procaine penicillin alone, have proved successful (Rantasalo, Salo, and Wallenius, 1964) although there are few data concerning the serum levels so obtained. These two penicillins combined with probenecid, which both enhances and prolongs the serum levels, could also be exploited.

Inadequate schedules involving single injections of crystalline penicillin $G$ have been rendered adequate by the use of probenecid even in areas where the gonococci are highly resistant (Jensen, Kvorning, and Nørredam, 1963). Complete success has been obtained in Greenland with single injections of 5 mega units crystalline penicillin $\mathrm{G}$ dissolved in $8 \mathrm{ml}$. lignocaine to lessen pain combined with one dose of 1 g. probenecid given 30 minutes before the injection (Lomholt and Berg, 1966). Success has also been obtained in the Far East by giving the same dose of probenecid one hour before a single injection of $2 \cdot 4$ mega units procaine penicillin $G$, followed by three doses of $0.5 \mathrm{~g}$. probenecid at 6 -hrly intervals; in this latter series the failure rate was reduced from 29 to 2 per cent. (Holmes and others, 1967a - Table VI), although approximately two-thirds of the patients developed a secondary non-gonococcal urethritis (Holmes, Johnson, Floyd, and Kvale, 1967b). In Australia, in cases of promiscuous women, complete success has also attended the use of 8-hrly injections of 2 mega units crystalline penicillin $\mathrm{G}$ combined with 2 g. probenecid twice daily for 4 days (Wren, 1967).

Depot penicillins, or mixtures containing them, are no longer recommended for the treatment of gonorrhoea, particularly in the case of promiscuous women, because they perpetuate resistance by the creation of a genetic pool for the Darwinian selection of the 'fittest' gonococci (Tawes, 1966).

\section{ORALLY ADMINISTERED PENICILLINS (Table XXXII)}

These have the disadvantage that absorption is less certain, particularly in relation to the ingestion of food (Table XXIV), and that patients cannot be relied upon to take their tablets as instructed. Because tablets may be saved up and later used for selftreatment or for the treatment of others, or may be disposed of on the 'black market', the number of doses to be taken away from the clinic must be kept to a minimum.

Phenoxymethyl penicillin, phenethicillin, and ampicillin can be used to maintain the high levels obtained by an initial large dose of benzyl penicillin, procaine penicillin, or fortified procaine penicillin. Phenoxymethyl penicillin is the cheapest for the purpose, although the blood levels tend to be somewhat variable (Santos-Buch, Koenig, and Rogers, 1957). For full efficiency a dosage of 2 mega units (1.2 g.) 4-hrly backed by probenecid is required (Table XXIII).

Ampicillin is the most effective oral antibiotic, but also the most expensive; because it is unlikely to be 
efficient alone in a single dose, multiple doses are necessary, although trials with probenecid are warranted.

\section{OTHER INJECTABLE ANTIBIOTICS (Table XXXIII)}

Streptomycin is now of little value against gonorrhoea because of the resistance of the gonococcus, and the injectable tetracyclines are of no value unless combined with oral therapy. Excellent cure rates may be obtained with single injections of chloromycetin succinate, but the use of this antibiotic is precluded by its toxicity. The best of this group are spectinomycin, which can cure by single injections but is not yet commercially available and requires reassessment in areas where the gonococci are highly resistant, and kanamycin, which also cures by single injections but is very expensive.

\section{OTHER ORALLY ADMINISTERED ANTIBIOTICS}

(Table XXXIV)

Of these the tetracyclines are the most suitable and, although the sensitivity findings in Taiwan suggest that some very highly resistant strains may exist there (Table IX) with an MIC only temporarily attainable by intravenous injection, complete success has been reported in the Far East using tetracycline hydrochloride in multiple doses (i.e. $1.5 \mathrm{~g}$. initially followed by $500 \mathrm{mg}$. four times a day for 4 days - Holmes and others, 1967a - Table VI), with only a quarter of the cases developing secondary non-specific urethritis. The tetracycline phosphate complex and the newer tetracyclines may allow the adoption of simpler dosage schedules.

Erythromycin in multiple dosage is worth exploitation while there is yet time, but if spiramycin is used high multiple doses will be required. Oleandomycin is less effective.

Chloramphenicol is by far the cheapest of this group but its routine use cannot be recommended because of its toxicity.

Newer agents, such as pristinomycin and rifampicin, merit further research as do the sulphonamides combined with trimethoprim; preliminary reports on rifampicin (Willcox, Morrison, and Cobbold, 1970) and on the sulphonamide-trimethoprim combination (Csonka and Knight, 1967; Schofield, Moffett, Masterton, and McGill, 1969; Carroll and Nicol, 1970) are encouraging, and the sulphonamides have been given a new lease of life.

\section{Choice of treatment in South-East Asia and the Far East (Appendix II)}

Relating the mean blood level obtained in a few subjects to the MIC of the organism, which varies widely between problem and selected strains, in order to select an optimum treatment schedule is not as simple as it first appears. There is obviously a continuing need for clinical research to determine the results obtained in practice, if necessary on a cooperative basis to obtain the required numbers of patients (see Table III), particularly in relation to the sensitivities in vitro of the infecting strains (Reyn and Bentzon, 1968).

On the basis of the available information and taking epidemiological and economic considerations into account, some schedules are suggested which should be suitable for use in areas where the gonococci are highly resistant and conventional schedules have failed. Those by which a cure may be achieved at a single session, and are therefore the first choice, are outlined in Table XXXV. Those which combine one injection and a single oral dose of tablets or capsules to be taken away by the patient are given in Table XXXVI (for use if and when the previous schedules should become inadequate). Those involving multiple injections or multiple doses of tablets, which are better reserved for special cases and individuals likely to be co-operative, are given in Table XXXVII.

In general, owing to the greater likelihood of closed foci of infection, the treatment time required for females is double that for males, as indicated in the Tables.

\section{Summary and conclusions}

(1) The situation in South-East Asia arising from the development of resistance of the gonococcus to antibiotics - notably penicillin - is reviewed. Taking into account wide individual variations in serum levels, several possible treatment schedules for future use are outlined.

(2) In countries free from social or political turmoil, with limitations on prostitution and widespread clinic and contact-tracing services, where antibiotics are not procurable except on a doctor's prescription, where self-treatment or sub-curative treatment of undiagnosed gonorrhoea is rare, and where several effective (if more costly) antibiotics are readily available for use against resistant gonococci, the situation has so far been largely kept in check by increasing the dose. This has been recommended on the INTERNATIONAI (Brit. F. vener. Dis., 1961; WHO, 1963), NATIONAL (Holmes and others, 1967a), and PERSONAL (Storck, Müller, and Rinderknecht, 1966) levels-despite the probability of the occasional importation into such countries of more resistant organisms from abroad (Warren, 1968).

(3) The environmental situation in South-East Asia is not conducive to the control of gonorrhoea. The adoption of treatment practices which give 
more favourable results may temporarily reverse the resistance of the gonococci in affected areas (Letchner and Nicol, 1961; Morton, 1963; Ödegaard and Gjessing, 1967), but where there is marked resistance, and environmental conditions differ widely from the 'ideal', the longterm results are likely to be unsatisfactory unless treatment is adequate to deal with all the circulating resistant strains of gonococci-regardless of degree of sensitivity. The object should be to achieve the most effective treatment in relation to the administrative and practical realities of the environment, and this implies higher costs to the health authorities.

(4) More research is required by manufacturers to develop concentrated injectable penicillins, to evolve delayed-action probenecid compounds and to introduce new antibiotics capable of cure by single session therapy. There is a continuing need for monitoring services to identify the prevailing resistance of circulating gonococci in different areas. Intensified investigations by WHO in this sector are recommended. Moreover, much more information is required concerning the serum and tissue levels obtained with the antibiotic doses used against the gonococci and their relationship to the levels obtained at the site of infection in successful and unsuccessful treatment.

(5) Successful treatment is judged mainly by the results obtained in patients as appraised by the clinician, but it is essential that such studies be linked to appropriate laboratory investigations. Organized clinical and laboratory research should be encouraged, as well as the reporting of the results of treatment. Such research should include sensitivity determinations in vitro of the gonococcal strains concerned as well as estimations of the serum and tissue levels of the antibiotics which are needed to effect a cure.

\section{References}

AEPINUS, M. (1965) Z. Haut- und Geschl.-Kr., 39, 11

Alergant, C. D. (1958) Brit. F. vener. Dis., 34, 36

- (1963) Ibid., 39, 225

- (1965) 'Proceedings of Symposium on Ampicillin, Brussels', pp. 80-83

Allison, J. R. (1961) Antibiot. and Chemother., 11, 454

- (1962) Ibid., 12, 367

ANĞ, O., and ONER, A. (1965) Istanbul Univ. Tip. Fak. Med., 28, 251

ashmalla, G., Walters, N. R., and Crahan, M. (1966) F. Amer. med. Ass., 195, 1115

Barile, M. F., Van ZeE, G. K., and Yaguchi, R. (1959) Antibiot. Med. (Brit. ed.), 6, 470

BARKer, B. M. (1968) Personal communication
Batchelor, F. R., Doyle, F. P., Nayler, J. H. C., and Rolinson, G. N. (1959) Nature (Lond.), 183, 257

BeEkman, E. M. (1965) Dermatologica (Basel), 131, 262

BELDA, W. O. (1965) Hospital (Rio de F.), 67, 879

BERRY, B. E. (1967) F. Amer. med. Ass., 202, 657

BEST, W. R. (1967) Ibid., 201, 181

Beyer, K. H., Flippin, H., VerWey, W. F., and WOODWARD, R. (1944) Ibid., 126, 1007.

BJÖRNBERG, A. (1964) Acta derm.-venereol. (Stockh.), 44, 460

BODENBENDER, R. H. (1960) U.S. armed Forces med. F., 11,1311

Boger, W. P., Crosley, A. P., Carfagno, S., and Bayne, G. M. (1952) Antibiot. and Chemother., 2, 555

BøgGILD, J. (1965) Ugeskr. Laeg., 127, 483

Bond, J. M. (1964) Postgrad. med. F., 40, Suppl., p. 17.

Boneli, J., Coutinho, A., and CANuto, J. (1966) Hospital (Rio de F.), 70, 921

Brit. F. vener. Dis. (1961) 37, 89

Brit. med. F. (1967) 1, 649

Bunn, P. (1959) Med. Clin. N. Amer., 41, 521

Bushby, S. R. M., and Harkness, A. H. (1946) Lancet, 2, 783

Capp, A. B., Goncalves, H. D., Silva, P., Coutinho, A. DA R., Pannunzio, M., and Cohen, A. (1965) Hospital (Rio de f.), 68, 1329

CARPENTER, C. M. (1961) Bull. Wld Hlth Org., 24, 321

-, Ackerman, H., Winchester, M. E., and WhitTLE, J. (1944) Amer. F. publ. Hlth, 34, 250

Carroll, B. R. T., and Nicol, C. S. (1970) Brit. F. vener. Dis., 46, 31

CHacko, C. W., and Yogeswari, L. (1966) Indian f. med. Res., 54, 823

Chinn, B. D., Putnam, L. E., Taggart, S. R., and Herwick, R. P. (1947) Amer. F. Syph., 31, 268

Clark, J. W., Yobs, A. R., and Post, W. E. (1964) Brit. F. vener. Dis., 40, 53

Clarke, G. H. V. (1964) Ibid., 40, 122

Cobbold, R. J. C., Morrison, G. D., Spitzer, R. J., and Willcox, R. R. (1970) Postgrad. med. F., 46, 142.

$\longrightarrow,-$, and WILlcox, R. R. (1968) Brit. med. F., 4, 681

CoHEN, R. L. (1950) Lancet, 1, 622

Cradock-Watson, J. E., Shooter, R. A., and Nicol, C. S. (1958) Brit. med. F., 1, 1091

CsonkA, G. W. (1967) Postgrad. med. f., 43, Suppl., p. 63

— and KNIGHT, G. J. (1967) Brit. F. vener. Dis., 43, 161

- and Murray, M. (1967) Postgrad. med. F., 43, Suppl., p. 123

Curtis, F. R., and Wilkinson, A. E. (1958) Brit. $\mathcal{F}$. vener. Dis., 34, 70

DamesheK, W. (1960) f. Amer. med. Ass., 174, 1853

Delouche, L. (1961) Presse méd., 69, 1035

Domescik, G., McLone, D. G., SCOTti, A., and MACKey, D. M. (1969) Publ. Hlth Rep. (Wash.), 84, 182

Dunlop, E. M. C. (1949) Brit. F. vener. Dis., 25, 81

DUREL, P. (1961) Ibid., 37, 107

—, Roiron, V., and Delouche, L. (1961) Bull. Wld Hlth Org., 24, 343

Epstein, E. (1959) f. Amer. med. Ass., 169, 1055

Evans, A. J. (1966) Brit. F. vener. Dis., 42, 251 
Fernandes, G. (1965) Indian f. Derm. Vener., 31, 72

Fluker, J. L., and HewitT, A. B. (1969) Brit. f. vener. Dis., 45, 317

Fowinkle, E., Guthrie, N., Griffith, T., and Duncan, J. (1966) f. Tenn. med. Ass., 59, 1115

Fowler, B. J. (1956) Brit. F. clin. Pract., 10, 651

Fowler, W. (1969) 'Proc. Symp. Clinical Evaluation of Cephalexin, Royal Society of Medicine, June, 1969', p. 54. Glaxo, Greenford, Middlesex

Gable, G. R., Romansky, M. J., and Taggart, S. R. (1953) Amer. F. Syph., 37, 377

Gangarosa, E. J., and Cary, S. G. (1960) f. Amer. med. Ass., 173, 1808

Garrod, L. P. (1965) Practitioner, 195, 36

Gästrin, B., and Kallings, L. O. (1964) Acta derm.venereol. (Stockh.), 44, 286

Gentele, H., Lagerholm, B., and Lodin, A. (1960) Ibid., 40, 256

Grosh, S., and Grosh, R. (1960) Indian f. Derm. Vener., 26, 123

Gibaldi, M., and Schwartz, M. A. (1968) Clin. Pharmacol. Ther., 9, 345

Gjessing, H. C. (1963) Nord. Med., 70, 866

and ÖDEGAARD, K. (1962) Brit. F. vener. Dis., 38, 26

—— (1965) Ibid., 41, 48

- - (1967) Ibid., 43, 133

Golosovker, A. M. (1961) Vestn. Derm. Vener., 35, (April), p. 52

Gray, I. R., Tai, A. R., Wallace, J. G., and Calder, J. H. (1964) Postgrad. med. F., 40, Suppl., p. 105

Greaves, A. B., Macdonald, G. R., Romansky, M. J., and TAGGART, S. R. (1950) f. vener. Dis. Inform., 31, 261

Griffith, R. S., and Peck, F. B. (1958) Antibiot. and Chemother., 8, 143

Grin, E., and KarLovac, K. (1965) Med. Arh. (Sarajevo). 19,5

Gundersen, T., ÖdegaArd, K., and GJessing, H. J. (1969) Brit. F. vener. Dis., 45, 235

Guthe, T., Reynolds, F. W., KRAG, P., and Willcox, R. R. (1953) Brit. med. F., 1, 594

HAwkINs, L. A., and LEDERER, H. (1952) Ibid., 2, 423

Heinemann, S., and Vinikoff, M. R. (1965) Med. Tms (N.Y.), 93, 290

HejzLaR, M., and Výmola, F. (1965) Cs. Derm., 40, 23

HerRell, W. E., Heilman, F. R., and Wellman, W. E. (1950) Ann. N.Y. Acad. Sci., 53, 448

Hilton, A. L. (1959) Brit. F. vener. Dis., 35, 249

- (1961) Ibid., 37, 207

Ho, Ting-Jao, and Chang, Shueh-Shen (1967) Far East med. F., 3, 320

Holmes, K. K., Johnson, D. W., and Floyd, T. M. (1967a) F. Amer. med. Ass., 202, 461

$\longrightarrow,-,-$, and KVALE, F. A. (1967b) Ibid., 202, 467

Hooton, W. F., and Nicol, C. S. (1967) Postgrad. med. f., 43, Suppl., p. 68

HoRne, G. O. (1950) Brit. F. vener. Dis., 26, 23

Hughes, R. P., and Carpenter, C. M. (1948) Amer. $\mathcal{F}$. Syph., 32, 265

IRoNs, E. N. (1950) f. Amer. med. Ass., 142, 97

f. Amer. med. Ass. (1967) (Editorial) 202, 538
Jacoby, A., and Ollswang, A. H. (1950) Amer. F. Syph., 34, 60

JefFeriss, F. J. G., and Rosedale, N. (1961) Brit. F. vener. Dis., 37, 161

Jensen, P. E., Kvorning, S. A., and Nørredam, K. (1963) Ibid., 39, 238

Jones, P. F., and Shooter, R. A. (1948) Brit. med. F., 2, 933

JUHLIN, I., and KROOK, G. (1965) Läkartidningen, 62, 1250

Kabins, S. A., Eisenstein, B., and Cohen, S. (1965) $\mathcal{F}$. Amer. med. Ass., 193, 165

Kallings, L. O., and Gästrin, B. (1966) Nord. Med., 76, 800

KJellander, J. O., and FinLand, M. (1963) New Engl. F. Med., 269, 834

Klaschka, F., Hannemann, G., and Ränike, A. (1963) Dermatologica (Basel), 127, 269

Knudsen, E. T. (1964) Postgrad. med. F., 40, Suppl., p. 14

Knudsen, H. E., and Perdrup, A. (1963) Acta derm.venereol. (Stockh.), 43, 235

Kunin, C. M., Dornbush, A. C., and Finland, M. (1959) F. clin. Invest., 38, 1950

Lagerholm, B., Lodin, A., and Nystrøm, B. (1966) Acta derm.-venereol. (Stockh.), 46, 345

LAIRD, S. M., and TAYLOR, G. (1962) Brit. F. vener. Dis., 38, 60

LeIGH, D. A. (1968) Personal communication

LejMAN, K., Kowarz-SokolowsKa, H., Stapiński, A., and Starzycki, Z. (1965) Przegl. Derm., 52, 105

Lentz, J. W., MacVicar, D. N., and Beilstein, H. R. (1962) Publ. Hlth Rep. (Wash.), 77, 653

LetCHNER, E. H., and Nicol, C. S. (1961) Brit. F. vener. Dis., 37, 158

Lewis, C. N., Putnam, L. E., Hendricks, F. D., Kerlan, I., and WeLCH, H. (1952) Antibiot. and Chemother., 2, 601

Lomholt, G., and Berg, O. (1966) Brit. F. vener. Dis., 42, 1

LuCAS, J. B. (1968) Personal communication

-, Price, E. V., Thayer, J. D., and Schroeter, A. (1957) New Engl. F. Med., 276, 1454

—, Thayer, J. D., Utley, P. M., Billings, T. E., and HaCKNEY, J. E. (1966) F. Amer. med. Ass., 195, 919

Lyng, B. (1963) Brit. F. vener. Dis., 39, 236

Mclone, D. G., Billings, T. E., Lucas, J. B., Hardegree, W. E., and Hackney, J. F. (1968) Publ. Hlth Rep. (Wash.), 83, 87

—, Kiley, J. D., and HaCkney, J. F. (1967) Brit. F. vener. Dis., 43, 166

Manning, P. R., Jones, P. N., and Bigham, R. S. (1954) Amer. F. Syph., 38, 110

Marmell, M., and Prigot, A. (1961) N.Y. St. F. Med., 61, 2609

- Sills, J. R., Brown, C. D., and Prigot, A. (1964) Ibid., 64, 985

Marshall, M. J., and Curtis, F. R. (1967) Postgrad. med. f., 43, Suppl., p. 121

Mead, R. K., MoON, N. F., and Bean, L. L. (1960) U.S. armed Forces med. F., 11, 1117

Meads, M., KNIGHT, V. H., and Izlar, H. L. (1951) Sth. med. F., 44, 297 
Medical Research Council (1961) Lancet, 2, 226

MEYER-RoHN, J. (1964) Dtsch. med. Wschr., 89, 2197

MOORE, M. B., ShoRT, D. H., Matheson, T. E., KNox, J. M., and VanderStoep, E. M. (1963) Publ. Hlth Rep. (Wash.), 78, 261

Morton, R. S. (1963) Brit. F. vener. Dis., 39, 105

- and Higson, D. W. (1966) Ibid., 42, 175

Nicoletti, N. (1962) Dermatologia (Napoli), 13, 235

ÖDEgaARD, K. (1962) Brit. med. F., 1, 645

— and GJessing, H. C. (1967) Brit. F. vener. Dis., 43, 284

OlLER, L. Z. (1964) Ibid., 40, 256

- (1967a) Postgrad. med. F., 43, Suppl., p. 24

_ (1967b) Brit. F. vener. Dis., 43, 39 (1968) Paper presented to MSSVD meeting at Cardiff in May, 1968

— and SMITH, H. C. (1959) 'Proc. Symp. Clinical Evaluation of Cephalexin, Royal Society of Medicine, June, 1969', p. 51. Glaxo, Greenford, Middlesex

Olon, L. P., and Holvey, D. N. (1968) Clin. Med., 75, 33

Piguet, B. (1961) Brit. F. vener. Dis., 37, 244

- (1962) Proph. sanit. morale, 34, 198

Pochi, P. E., and Strauss, J. S. (1961) Antibiot. Med., 8, 75

Practitioner (1967) 198, 568

Prince, L. N., Randall, E. L., Lentz, J. W., and Shapiro, L. H. (1964) Amer. F. Obstet. Gynec., 90, 202

Puchi F., J. A., Flores M., E. J., and Duarte, C. R. (1967) Dermatologia (Venezolana), 6, 171

PUlaski, E. J., and ConNell, J. F. (1949) New Engl. F. Med., 241, 514

QuinN, E. L. (1964) Postgrad. med. F., 40, Suppl., p. 23

RANade, S. N., KalyanPuRKaR, S. S., Dubhashi, A. R., and WABALE, S. M. (1961) F. Indian med. Ass., 36, 241

Rantasalo, I. (1962) Duodecim (Helsinki), 78, 372

-, Salo, O. P., and Wallenius, J. O. (1964) Brit. $\mathcal{F}$. vener. Dis., 40, 273

ReEs, E. (1952) Ibid., 28, 115

- (1967) Ibid., 43, 150

Rev. int. Serv. Santé Armées. Abstr. in Liège méd. (1965) 38, 117

ReYN, A. (1961) Brit. F. vener. Dis., 37, 145 (1963) Acta derm.-venereol. (Stockh.), 43, 380 (1968) Material from WHO Neisseria Centre, Copenhagen. Personal communication to WHO

- and Bentzon, M. W. (1963) Acta derm.-venereol. (Stockh.), 43, 394

__ (1968) Brit. F. vener. Dis., 44, 140

- - - and ERICsson, H. (1963) Acta path. microbiol. scand., 57, 235

- KORNER, B., and Bentzon, M. W. (1958) Brit. F. vener Dis., 34, 227

Riboldi, A. (1966) Minerva Derm., 41, 35

Rich, M. L., RitTerhoff, R. J., and HOFfmanN, R. J. (1950) Ann. intern. Med., 33, 1459

Robinson, O. P. W. (1964) Brit. F. clin. Pract., 18, 593

Robinson, R. C. V. (1950) Amer. F. Syph., 34, 187

- and GaleN, W. P. (1951) Ibid., 35, 488

RöckL, H. (1962) Münch. med. Wschr., 104, 1169

ROHDE, B., and MEYER-RoHN, J. (1961) Hautarzt, 12, 466

Roiron, V., Rasetti-Nicod, G., and Durel, P. (1961) Ann. Inst. Pasteur, 100, 445

Rolinson, G. N. (1964) Postgrad. med. F., 40, Suppl., p. 21

Rose, G. (1968) Personal communication
Sabath, L. D., and Kivlahan, J. J. (1961) Amer. F. med. Sci., 242, 663

Sanders, A. C., Pelczar, M. J., and Hoefling, A. E. (1962) Antibiot. and Chemother., 12, 10

S.anjurjo, L. A., and Rodriguez, S. (1964) Trans. Amer. Ass.gen.-u'in. Surgns, 56, 135

Santos-Buch, C. A., Koenig, M. G., and Rogers, D. E. (1957) New Engl. f. Med., 257, 249

Schmid, H. (1962) Nord. Med., 68, 1479

-, Niordson, A.-M., Reyn, A., and Bentzon, M. W. (1955) Brit. F. vener. Dis., 41, 120

- and RoHоLT, K. (1965) Ugeskr. Laeg., 127, 478

SChofield, C. B. S., Moffett, M., MASTERTon, G., and McGill, M. I. (1969) Postgrad. med. F., 45, Suppl, (November), p. 81

SChwimmer, B., Henderson, N. D., and Olson, B. N. (1961) Publ. Hlth Rep. (Wash.), 76, 630

Scott, J., and Stone, A. H. (1966) Brit. F. vener. Dis., 42, 103

Seftel, H. C., SiefF, B., and Richardson, N. J. (1966) Med. Proc., 12, 29

Shapiro, L. H., and Lentz, J. W. (1963) Amer. f. Obstet. Gynec., 87, 87.

- - (1965) Ibid., 94, 536

- (1967) Ibid., 97, 968

Sharp, A. A. (1963) Brit. med. F., 1, 735

Sheehan, J. C., and HenerY-Logan, K. R. (1957) $\mathcal{F}$. Amer. chem. Soc., 79, 1262

SheIL, L. P. (1956) Brit. F. vener. Dis., 32, 251

Shidlovsky, B. A., Prigot, A., Maynard, A. De L., Felix, A. J., HJelt-Harvey, I. (1958) 'Antibiotics Annual, 1957-1958', p. 459

Siboulet, A., and Durel, P. (1961) Brit. F. vener. Dis., 37,240

SissmanN, R. (1962) Gaz. méd. Fr., 69, 1601

SMEDLEY, M. G. (1960) f. roy. Nav. med. Serv., 46, 119

Smith, D. D., and Levey, J. M. (1967) Med.F. Aust., 1, 849

Sмith, E. B. (1966) Milit. Med., 131, 345

- (1967) Curr. ther. Res., 9, 79

SMITH, J. LAWTON (1968) Paper presented to the M.S.S.V.D., London

SNell, E., Norris, D. A., and Strong, J. (1963) Canad. med. Ass. F., 89, 601

Sokoloff, B. (1965) Clin. Pharmacol. Ther., 6, 350

and Goldstern, H. (1963) f. Amer. med. Ass., 184, 197

SpItzer, R. J., and Willcox, R. R. (1968) Acta derm.venereol. (Stockh.), 48, 537

Staheli, L. T. (1964) F. Amer. med. Ass., 190, 854

Stebbins, P. L. (1967) Milit. Med., 132, 535

Stepniak, R. (1961) Przegl. Derm., 48, Suppl., p. 331

STORCK, H., MüLleR, P., and RINDERKNECHT, P. (1966) Schweiz. med. Wschr., 96, 1635

Svihus, R. H., LuCERo, B. M., MikolajCzyK, R. J., and CARTER, E. E. (1961) f. Amer. med. Ass., 177, 121

Sylvestre, L., and Ethier, J. (1963) Un. méd. Can., 92, 1411

TaI, F. H., and Han, S. H. (1960) F. Formosan med. Ass., 59,1471

TAWES, R. L., JR. (1966) Brit. F. vener. Dis., 42, 155

ThaYer, J. D., Field, F. W., MAgnuson, H. J., and Garson, W. (1957) Antibiot. and Chemother., 7, 306

-, Samuels, S. B., Martin, J. E., and Lucas, J. B. (1965) In 'Antimicrobial Agents and Chemotherapy, 1964', ed. J. C. Sylvester, p. 433

TiedemanN, J. H. (1962) Sth. med. F., 55, 852 
- Hackney, J. F., and Price, E. V. (1965) F. Amer. med. Ass., 191, 89

- - - Simpson, W. G., and Price, E. V. (1962) Publ. Hlth Rep. (Wash.), 77, 485

Utley, P. M., Lucas, J. B., and Billings, T. E. (1966) Sth. med. F., 59, 1271

VanderStoep, E. M., Matheson, T. E., Moore, M. B., ShorT, D. H., and KNox, J. M. (1964) Ibid., 57, 201

Verma, B. S., Gulati, O. D., Gokhale, S. D., and Byakod, B. G. (1965) Indian f. Derm. Vener., 31, 2 C9

Vermeer, J. H., and SchaAp, G. J. P. (1962) Ned. T. Geneesk., 106, 1025

WAGNER, W. H. (1954) In ' 3 rd International Congress of Chemotherapy, Stuttgart, 1963: Proceedings', vol. 2, p. 1716. Thieme, Stuttgart

WARREN, R. M. (1968) Brit. F. vener. Dis., 44, 80

Watling, W. J. T. (1968) Personal communication

Welch, H. (1950) Ann. N.Y. Acad. Sci., 53, 253

White, A. C., Couch, R. A., Foster, F., Calloway, J., Hunter, W., and KNIGHT, V. (1956) 'Antibiotics Annual, 1955-56', p. 490

W.H.O. (1963) 'W.H.O. Expert Committee on Gonococcal Infections: First Report'. W.H.O. Tech. Rep. Ser., No. 262

Wilkinson, A. E. (1968) Personal communication

-, RACE, J. W., and Curtis, F. R. (1967) Postgrad. med. F., 43, Suppl., pp. 63, 65

Willcox, R. R. (1956) Brit. F. vener. Dis., 32, 117

- (1958) Ibid., 34, 118

(1961) Bull. Wld Hlth Org., 24, 307

(1962a) Brit. F. vener. Dis., 38, 57

(1962b) Ibid., 38, 150

(1962c) Acta derm.-venereol. (Stockh.), 42, 484

(1963) Ibid., 43, 399

(1964a) Ibid., 40, 118

(1964b) Postgrad. med. F., 40, Suppl., p. 202

(1967) Ibid., 43, 157

(1968) In 'Current Problems in Dermatology', vol. 2,

'Antibiotic Treatment of Venereal Diseases', ed. A.

Luger, p. 101. Karger, Basel

(1969) Clin. Trials f., 6, 152

(1970a) Paper given at International Conference on Cephalosporins, Brighton, May 1970. Unpublished

(1970b) Acta derm.-venereol. (Stockh.), 50, 154

and Mallet, J. K. H. (1962) Ibid., 42, 195

, Morrison, G. D., and CobBold, R. J. C. (1970) Brit.

f. vener. Dis., 46, 145

Winningham, D. G., Nemoy, N. J., and Stamey, T. A. (1968) Nature (Lond.), 219, 139

Wolman, B. (1952) Brit. med. F., 2, 426

Wormer, D. C., Martin, W. J., Nichols, D. R., HeilMAN, F. R., and Rose, D. (1955) Antibiot. Med., 1, 589

Wren, B. G. (1967) Med. F. Aust., 1, 847

ZipRKowsKi, I., KRAKowski, A., and Roubenoff, D. (1961) Harefuah, 61, 121

Examen des problèmes du traitement antibiotique de la gonococcie, avec reference speciale à l'Asie du Sud-Est

\section{SOMMAIRE}

(1) On étudie la situation qui se manifeste dans l'Asie du Sud-Est quant au développement de la résistance du gonocoque aux antibiotiques-en particulier à la pénicilline.
En tenant compte des importantes variations individuelles des taux sanguins, plusieurs types de traitement $\frac{\square}{\omega}$ peuvent être esquissés pour l'avenir.

(2) Dans un pays sans troubles sociaux ou politiques, où l'importance de la prostitution est limitée, où les cliniques읃 et les services de recherche des contaminateurs sont largement répandus, où les antibiotiques ne peuvent être $\frac{\bar{\Phi}}{\mathcal{T}}$ obtenus que sur prescription médicale, où les auto- $\mathbb{Q}$ traitements ou les traitements subcuratifs de la gonococcie sans diagnostic sont rares et où plusieurs antibiotiques ${ }^{\infty}$ efficaces (même si coûteux) peuvent être aisément $\overrightarrow{0}$ employés contre les gonocoques résistants, la situation a $\overrightarrow{\vec{t}}$ été jusqu'ici, en grande partie, tenue en échec par l'aug- $\vec{\omega}$ mentation de la dose. Cette augmentation a été recommandée sur le plan INTERNATIONAL (Brit. $\mathfrak{f}$. vener. Dis., 1961 ; OMS, 1963), NATIONAL (Holmes et coll., 1967a), के autant que par divers auteurs (Storck, Müller, et $\dot{\omega}$ Rinderknecht, 1966) en dépit de la probabilité d'importa- î tion occasionnelle dans de tels pays d'organismes plus $\vec{V}$ résistants en provenance d'autres contrées (Warren, 1968). 음

(3) Les conditions générales de la situation dans l'Asie du $\vec{c}$ Sud-Est ne favorisent pas le contrôle de la gonococcie. L'adoption de techniques thérapeutiques donnant des $\overparen{D}$ résultats plus favorables peuvent temporairement lutter $\vec{\varphi}$ contre la résistance des gonocoques dans de telles régions (Letchner et Nicol, 1961; Morton, 1963; Ödegaard et Gjessing, 1967) mais là où la résistance est importante et les conditions locales très largement éloignées de l'idéal', les résultats à long terme sont susceptibles de ne pas être $\bar{O}$ satisfaisants, à moins de disposer d'un traitement adéquat concernant toutes les souches résistantes de gonocoques $\stackrel{\circ}{\mathbb{Q}}$ en circulation-sans tenir compte du degré de sensibilité. Le but doit être d'obtenir le traitement le plus efficace en $\overline{\hat{O}}$ rapport avec les réalités administratives et pratiques locales; ceci signifie des dépenses plus élevées pour les autorités sanitaires.

(4) Davantage de recherches sont requises des fabricants pour trouver des pénicillines injectables concentrées et des $\frac{\sigma}{3}$ composés à action prolongée à base de probénécid et pour mettre à la disposition du corps médical des antibiotiques o nouveaux capables d'agir en une seule séance. Il est $₹$ nécessaire de disposer d'une manière constante de services 음 aptes à surveiller continûment le degré de résistance de gonocoques dans les différentes régions. Des recherches de l'OMS doivent être intensifiées à ce point de vue. En outre, beaucoup plus d'informations sont requises $\mathrm{N}$ concernant les taux d'antibiotiques obtenus dans le sérum et les tissus avec les doses employées contre les gonocoques et la relation entre ces taux au siège de $\omega$ l'infection lors de traitements efficacaes ou inefficaces.

(5) C'est principalement par les résultats obtenus chez les malades tels qu'ils apparaissent au clinicien que l'on $\$$ juge du succès d'un traitement, mais il est essentiel de? lier ces études à des investigations appropriées de laboratoire. Des recherches conjointes de clinique et de labora- $\frac{O}{\Phi}$ toire doivent être encouragées, en même temps que $\stackrel{\rho}{\mathscr{P}}$ seront rapportés les résultats du traitement. De telles $\underset{\mathbb{Q}}{\overparen{Q}}$ recherches doivent comprendre aussi bien des détermina- $\bar{\sigma}$ tions de sensibilité, in vitro, des souches de gonocoques considérées que des informations sur les taux d'antibio-응 tiques dans le sérum et les tissus qui sont nécessaires pour obtenir la guérison. 


\section{Appendix I \\ Tables XXXI-XXXIV}

TABLE XXXI The injectable penicillins used for gonorrhoea

\begin{tabular}{|c|c|c|}
\hline Preparation & Experience & Disadvantages and comment \\
\hline Aqueous procaine penicillin & $\begin{array}{l}\text { Reasonably good results in some areas with: } \\
1.2-1.8 \text { m.u. (Klaschka, Hanneman, and } \\
\text { Ranike, 1963; Marshall and Curtis, 1967) } \\
\text { or } 2.4 \mathrm{~m} . \mathrm{u} \text {. (Sokoloff and Goldstein, 1963; } \\
\text { Staheli, 1964; Ashamalla, Walters, and }\end{array}$ & $\begin{array}{l}\text { High failure rates with single injections of } \\
2.4 \text { m.u. in Far East (Holmes and others, } \\
1967 \mathrm{a} \text { ) } \\
\text { Limits of injectability reached for single in- } \\
\text { jections }\end{array}$ \\
\hline
\end{tabular}

\author{
Repository (depot) penicillins \\ Benzathine \\ Benethamine \\ PAM
}

\section{Crystalline benzyl penicillin $\mathrm{G}$} plus procaine penicillin

\section{Crystalline benzyl penicillin $\mathrm{G}$ plus procaine penicillin plus repository}

\section{Ampicillin}

\section{Cephalosporins \\ Synnematin B \\ Cephalothin \\ Cephaloridine}

$$
\text { Crahan, 1966) }
$$

Although good results claimed in some areas (e.g. South America: Bonelli, Coutinho, and Canuto, 1966), will fail in others (e.g. Greenland; Lomholt and Berg, 1966)

Have been widely used in treatment of developed and incubating syphilis

Value in preventing early re-infection with gonorrhoea not proved (Fowinkle, Guthrie, Griffith, and Duncan, 1966)

Three parts procaine to one part benzyl

Useful in single injection in some areas (Rees, 1967)

(a) 'Triplopen' $(500,000 \mathrm{u}$. benzyl, $250,000 \mathrm{u}$ procaine, $500,000 \mathrm{u}$. benethamine)

Single injections of $2.5 \mathrm{~m}$.u. effective in some areas (Scott and Stone, 1966)

(b) 'Penidural All-Purpose' (300,000 u. benzyl, $300,000 \mathrm{u}$. procaine, $600,000 \mathrm{u}$. benzathine)

Blood levels with $0.5 \mathrm{~g}$. injected as good as or better than those with $1 \mathrm{~g}$. by mouth (Robinson, 1964)

Results indifferent with single injections of 250-500 mg. (Table II)

Good results if combined with oral dose (Alergant, 1965)

Early cures with Synnematin B (Schwimmer, Henderson, and Olson, 1961)

Cephaloridine has given $90-95$ per cent. cures in single injections of $2 \mathrm{~g}$. (Lucas, Thayer, Utley, Billings, and Hackney, 1966; Seftel, Sieff, and Richardson, 1966; Marshall and Curtis, 1967; Oller, 1967a, b); others report less good results (Csonka and Murray, 1967) Cephalothin less useful (Smith, 1967)

Recommended for patients allergic to benzyl penicillin

\section{TABLE XXXII Orally administered and other penicillins}

\begin{tabular}{l} 
Preparation \\
\hline Orally administered \\
Benzyl penicillin
\end{tabular}

Panamecillin

\section{Experience}

When first introduced cure rates of 80-90 per cent. obtained with multiple dosage (Bushby and Harkness, 1946; Jacoby and Ollswang, 1950; Horne, 1950; Robinson, 1950)

Acid-resistant ester of penicillin G which circulates in serum as penicillin G (Practitioner, 1967)
Disadvantages and comment

Not acid resistant

Published data not relevant to present sensitivities

Replaced by acid-resistant penicillins

No reports as to use in gonorrhoea 
TABIE XXXII Continued

$\frac{\text { Preparation }}{\text { Phenoxymethyl penicillin (V) }}$

Phenethicillin

Ampicillin

Hetacillin

Penicillinase-resistant
Methicillin
Cloxacillin
Oxacillin
Nafcillin
Ancillin
Quincillin
Propicillin
Phenbenicillin
Cephalexin

Penicillinase-resistant

Methicillin

Nafcillin

Quincillin

Phenbenicilli

Cephalexin

\section{Experience}

Acid-resistant

Synthesized from 6-amino-penicillanic acid (Sheehan and Henery-Logan, 1957)

Good results with divided dosage (Sheil, 1956)

Approximately 80 per cent. cures with single or double dosage (Willcox, 1958)

\section{Acid-resistant}

Synthesized after discovery of economic source of 6-amino-penicillanic acid in fermentation broths (Batchelor, Doyle, Nayler, and Rolinson, 1959)

Excellent results with 3-4 g. over 2 days (Marmell and Prigot, 1961)

Indifferent results with single or double doses of $1 \mathrm{~g}$. (Hilton, 1961; Allison, 1962) although 82-85 per cent. cures obtained by others (Jefferiss and Rosedale, 1961; Willcox, 1962a)

Acid-resistant, broad spectrum

Considered more effective than others against less sensitive strains (Odegaard, 1962), but others (Reyn and Bentzon, 1968) consider penicillin $G$ and ampicillin to be equal in effectiveness weight for weight

Useful clinically in penicillin $G$ failures (Willcox, 1964a; Smith, 1966)

Excellent results with multiple doses (Marmell, Sills, Brown, and Prigot, 1964; Heinemann and Vinikoff, 1965)

Failure rate approx. 15 per cent. with single doses (Willcox, 1964a); others (Alergant, 1963, 1965) report better results, particularly with two split doses (Willcox, 1964b)

Can be combined in some areas with procaine penicillin (Alergant, 1965; Gjessing and Odegaard, 1965; Fluker and Hewitt, 1969) in a single session

Cures obtainable with multiple and sometimes single doses (Puchi, Flores, and Duarte, 1967)

Many (e.g. methicillin) not acid-resistant and have to be given by injection

Some also acid-resistant (e.g. cloxacillin) and can be also given orally

Single doses of $2 \mathrm{~g}$. unsatisfactory (Oller and Smith, 1969)

Approx. 85 per cent. success with two divided doses of $2 \mathrm{~g}$. or with single doses of $3 \mathrm{~g}$. plus 1 g. probenecid (Fowler, 1969; Willcox, 1970a)
Disadvantages and comment

Multiple dosage required

Worth exploiting as 'booster' to injection of procaine penicillin

Multiple dosage required

Worth exploiting as 'booster' to injection

Expensive

Can be used alone in multiple doses or as

'booster' to injection single oral doses of $2 \mathrm{~g}$. ampicillin plus

1 g. probenecid (Gundersen, Ódegaard, and Gjessing, 1969)

Said to be hydrolysed in the body to ampicillin

Relatively ineffective in gonorrhoea

Use reserved for infections with penicillinresistant staphylococci

Sensitivities to cephalosporins similar to penicillin

Can be used in penicillin-allergic subjects

TABLE XXXIII Other injectable antibiotics

\begin{tabular}{ll}
\hline Antibiotic & Experience \\
\cline { 1 - 2 } Streptomycin & Once produced 97 per cent. success (Chinn, \\
Putnam, Taggart, and Herwick, 1947) \\
Failure rates increased (Alergant, 1958; Will- \\
cox and Mallett, 1962) \\
Now fails in $31 \cdot 7$ per cent. of routine cases in \\
London, where it will fail in 85 per cent. by \\
1971 (Spitzer and Willcox, 1968)
\end{tabular}

Disadvantages

As strains less sensitive to penicillin are nearly always streptomycin-resistant and vice versa, $\Omega$ this antibiotic no longer has anything to $\mathbb{D}$ offer in the treatment of gonorrhoea 
TABIE XXXII Continued

\begin{tabular}{|c|c|c|}
\hline Antibiotic & Experience & Disadvantages \\
\hline $\begin{array}{l}\text { Tetracyclines } \\
\text { Tetracycline } \\
\text { Oxytetracycline } \\
\text { Pyrrolidinomethyltetracycline } \\
\text { (rolitetracycline) }\end{array}$ & $\begin{array}{l}\text { Although good results have been claimed from } \\
\text { single injections (Sylvestre and Ethier, 1963), } \\
\text { this has not been generally confirmed (Table } \\
\text { V). More recently cure rates of } 90-98 \cdot 4 \text { per } \\
\text { cent. have been reported with one injection } \\
\text { plus } 1 \text { g. orally at a single session (Shapiro } \\
\text { and Lentz, 1963, 1965; Prince, Randall, } \\
\text { Lentz, and Shapiro, 1964), or with injection } \\
\text { plus multiple oral doses (Berry, 1967) } \\
\text { Other preparations are being tried in this way }\end{array}$ & $\begin{array}{l}\text { Only relatively small amounts (e.g. } 250-500 \\
\text { mg.) can be injected } \\
\text { Some preparations have proved painful } \\
\text { Not suitable alone } \\
\text { May be combined with oral tetracyclines } \\
\text { (Willcox, 1970b) }\end{array}$ \\
\hline Chloromycetin & $\begin{array}{l}\text { Has been little used for gonorrhoea } \\
95 \text { per cent. cure rate reported with single in- } \\
\text { jections of chloromycetin succinate (Table V) }\end{array}$ & $\begin{array}{l}\text { Not suitable because of toxicity } \\
\text { See under Chloramphenicol (Table XXXI) }\end{array}$ \\
\hline Kanamycin & $\begin{array}{l}\text { Single injections of } 1 \mathrm{~g} \text {. inadequate (Piguet, } \\
\text { 1961), but excellent results with } 1 \mathrm{~g} \text {. given } \\
\text { daily for 2-3 days (Piguet, 1961, 1962; } \\
\text { Ziprkowski and others, 1961; Wilkinson and } \\
\text { others, } 1967 \\
\text { Cure rates above } 95 \text { per cent. with single in- } \\
\text { jections of } 2 \mathrm{~g} \text {. (Csonka 1967; Marshall and } \\
\text { Curtis } 1967 \text {; Wilkinson and others, 1967) } \\
2 \text { g. adequate in females (Hooton and Nicol, } \\
\text { 1967) } \\
\text { Gives good results so far in penicillin failures } \\
\text { Sensitivity findings not related to failures } \\
\text { Hooton and Nicol, } 1967 \text { ) } \\
\text { Unlike other antibiotics } 2 \text { g. does not prejudice } \\
\text { darkfield examination for } T \text {. pallidum } \\
\text { (Wilkinson and others, 1967) }\end{array}$ & $\begin{array}{l}\text { Can be ototoxic and nephrotoxic in patients } \\
\text { with renal disease } \\
\text { Little trouble so far in treatment of gonorrhoea } \\
\text { Very expensive }\end{array}$ \\
\hline Spectinomycin & $\begin{array}{l}\text { Cure rates above } 90 \text { per cent. with one injec- } \\
\text { tion of } 1.6-2 \mathrm{~g} \text {. (Willcox, 1962b, 1963; Laird } \\
\text { and Taylor, 1962; Tiedemann, Hackney, and } \\
\text { Price, 1965) } \\
\text { Useful in penicillin failures (Beekman, 1965) }\end{array}$ & $\begin{array}{l}4 \text { g. as effective in females as } 2.4 \text { m.u. procaine } \\
\text { penicillin but not more so (Lucas and others, } \\
\text { 1967) } \\
\text { Results less good in areas where results with all } \\
\text { antibiotics are less good (e.g. } 77.7 \text { per cent. } \\
\text { cure rate in Nigeria compared with } 66.6 \text { per } \\
\text { cent. with procaine penicillin: Clarke, 1964) } \\
\text { Is treponemicidal (Clark, Yobs, and Post, } \\
\text { 1964) } \\
\text { Requires evaluation in high resistance areas } \\
\text { Not yet commercially available }\end{array}$ \\
\hline
\end{tabular}

TABLE XXXIV Other antibiotics given orally

\begin{tabular}{|c|c|}
\hline Antibiotic & Experience \\
\hline $\begin{array}{l}\text { Established tetracyclines } \\
\text { Chlortetracycline } \\
\text { Oxytetracycline } \\
\text { Tetracycline }\end{array}$ & $\begin{array}{l}\text { With older established tetracyclines one dose of } \\
1 \text { g. usually insufficient but } 80 \text { per cent. } \\
\text { cures and more reported with } 2 \text { g. (Robinson } \\
\text { and Galen, 1951; Lentz, MacVicar, and } \\
\text { Beilstein, 1962; McLone, Kiley, and Hack- } \\
\text { ney, 1967) } \\
\text { Better results with two split doses at interval } \\
\text { of } 4-6 \text { hours (Willcox, 1968) } \\
\text { Best results with } 3 \mathrm{~g} \text {. phosphate-potentiated } \\
\text { tetracycline over 1-2 days (Golosovker, 1961; } \\
\text { Tiedemann, 1962; Tiedemann, Hackney, } \\
\text { Simpson, and Price, 1962; Moore, Short, } \\
\text { Matheson, Knox, and VanderStoep, 1963) } \\
\text { In Far East excellent results with } 1.5 \mathrm{~g} \text {. fol- } \\
\text { lowed by 500 mg. four times a day for } 4 \text { days } \\
\text { (Holmes and others, 1967a) }\end{array}$ \\
\hline
\end{tabular}

\section{Disadvantages and comment}

Multiple doses required

Patients have to take antibiotic away from clinic

There may be room for exploitation of the newer tetracyclines which carry a higher effective dose per weight, and also the combination of all with tetracycline by injection and by mouth 
TABLE XXXIV Continued

\begin{tabular}{|c|c|}
\hline Antibiotic & Experience \\
\hline $\begin{array}{l}\text { Newer tetracyclines } \\
\text { Demethylchlortetracycline } \\
\text { Limecycline } \\
\text { Methacycline } \\
\text { Clomocycline } \\
\text { Doxycycline } \\
\text { Mixed }\end{array}$ & $\begin{array}{l}\text { With newer more powerful demethylchlor- } \\
\text { tetracycline failure rates of } 7 \text { to } 11 \text { per cent. } \\
\text { recorded with single oral doses (Allison, } \\
1961 \text {; Pochi and Strauss, 1961; Moore and } \\
\text { others, 1963; VanderStoep, Matheson, } \\
\text { Moore, Short, and Knox, 1964), but poorer } \\
\text { results also reported (Sokoloff, } 1965 \text {; Will- } \\
\text { cox, 1967). Better results with two doses of } \\
1 \cdot 2 \text { g. (Willcox, 1967) and near } 100 \text { per cent. } \\
\text { success with multiple doses over } 1 \text { to } 2 \text { days } \\
\text { (Sokoloff, 1965; Bonelli and others, 1966) } \\
\text { Failure rate below 14 per cent. reported with } \\
\text { multiple doses of methacycline (6-methylene } \\
\text { tetracycline (Morton and Higson, 1966) } \\
\text { Newer derivatives (e.g. clomocycline) are under } \\
\text { investigation (Oller, 1968), and also mixed } \\
\text { preparations (Willcox, 1969) } \\
\text { Doxycycline recently claimed to give } 95 \text { per } \\
\text { cent. success with a single dose (Domescik, } \\
\text { McLone, Scotti, and Mackey, 1969), as also } \\
\text { methacycline (McLone, Billings, Lucas, } \\
\text { Hardegree, and Hackney, 1968) }\end{array}$ \\
\hline Chloramphenicol & $\begin{array}{l}\text { Little used, but } 90 \text { to } 96 \text { per cent. cure rate } \\
\text { reported with single oral doses (Greaves, } \\
\text { Macdonald, Romansky, and Taggart, 1950; } \\
\text { Tiedemann and others, 1962; Gjessing and } \\
\text { Odegaard, 1967), and when combined with } \\
\text { single injections of procaine penicillin } \\
\text { (Gjessing and Odegaard, 1967) } \\
\text { Its analogue, dextrosulphenidol, also effective }\end{array}$ \\
\hline
\end{tabular}

Its analogue, dextrosulphenidol, also effective (Table V)
Thiamphenicol

Erythromycin

Oleandomycin

Spiramycin

\section{Disadvantages and comment}

There is less secondary non-gonococcal urethritis after treatment in the Far East than with penicillin (Holmes and others, 1967a)

Because chloramphenicol and its analogue cause blood dyscrasias (Rich, Ritterhoff, and Hoffmann, 1950; Wolman, 1952; Hawkins, and Lederer, 1952; Best, 1967) due to the nitrobenzene radical in its structure, which may take several months to develop, their use should be strictly restricted to serious conditions in which it is primarily indicated (Dameshek, 1960; Sharp, 1963; Lewis, Putnam, Hendricks, Kerlan, and Welch, 1952; Brit. med. F., 1967). Such complications are apparently less common in those not of European race.

Although complications usually follow protracted treatment, and myelotoxic action may be potentiated by other drugs (Brit. med. f., 1967), small doses may sensitize bone marrow for later (Dameshek, 1960; Garrod, 1965)

Also depresses erythropoiesis to a greater extent than chloramphenicol, although aplastic anaemia not yet reported phonyl group substituted for nitro group

Less effective synthetic chloramphenicol-like substance

Effective in multiple dosage (1-5 g. over one week) (Belda, 1965)

Variable reports with single doses (Riboldi, 1966; Rev. int. Serv. Santé Armées, 1965)

Early reports (Gable, Romansky, and Taggart, 1953; Manning, Jones, and Bigham, 1954; Willcox, 1968) of 90 per cent. cure rate with $2 \mathrm{~g}$. over one day

More recent experience with erythromycin propionate over 2 days (Sissmann, 1962) has shown a failure rate of 13.3 per cent.

Restriction of use once recommended to infections with penicillin-insensitive staphylococci (Fowler, 1956) no longer necessary

Oleandomycin, including newer triacetyl oleandomycin, not satisfactory in single doses of 1-2 g. (Delouche, 1961; Nicoletti, 1962; Willcox, 1962c)

Best results with two doses given $12 \mathrm{hrs}$ apart.

Combined with tetracycline in 'Sigmamycin'

Ineffective in single doses of up to $2 \mathrm{~g}$. (Willcox, 1956)

Widely used in France in single doses of $2.5 \mathrm{~g}$. with up to 97 per cent. cure rate (Siboulet and Durel, 1961)

Results less striking in other areas (Clarke, 1964; Schmidt and others, 1965)

Doses of 3-4 g. spread over 1 to 2 days have been completely successful (Willcox, 1956) 
TABLE XXXIV Continued

Antibiotic

Rifampicin

Pristinomycin

Sulphonamides (not antibiotics)

Experience
$\begin{aligned} & \text { Ineffective (Verma, Gulati, Gokhale, and } \\ & \text { Byakod, 1965) }\end{aligned}$

New antibiotic stated to provide serum levels well above minimum inhibitory concentration after one dose of $900 \mathrm{mg}$.

Has given 11.9 per cent. failure rate (Cobbold, Morrison and Willcox, 1968) (Table V)

Cures apparently obtainable with single dose (Capp, Gonçalves, Silva, Coutinho, Pannunzio, and Cohen, 1965)

After early developed resistance (Carpenter, Ackerman, Winchester, and Whittle, 1944; Dunlop, 1949), laboratory evidence (Durel and others, 1961 ; Reyn, 1961; Schmidt, 1962; Odegaard and Gjessing, 1967) now suggests they have recovered some of their powers, but clinicians are experiencing failure rates of 33 to 40 per cent. (Ghosh and Ghosh, 1960; Ranade, Kalyanpurkar, Dubhashi, and Wabale, 1961; Csonka and Knight, 1967)

Occasional reports of better results (Fernandes, 1965)
Reported as active (Sanjurjo and Rodriguez, 1964)
Disadvantages and comment

Not indicated

Obtainable in Europe

Also effective in cases of tuberculosis

Limited experience

Failure rates in both sexes reduced from 33 to under 10 per cent. by use of sulphonamides combined with trimethoprim (Csonka and Knight, 1967; Schofield, Moffett, Masterton, and McGill, 1969; Carroll and Nicol, 1970)

Combined preparation of sulphamethoxazole and trimethoprim (Septrin; Bactrim) now available

Other work (e.g. Oller, 1964) and personal experience have shown indifferent results

\section{Appendix II}

\section{Tables XXXV-XXXVII}

TABLE XXXV Some suggested single-session procedures for treating gonorrhoea in areas of high resistance

\section{Schedule}

(1) Aqueous procaine penicillin $4.8 \mathrm{~m} . \mathrm{u}$. (with $1 \mathrm{~g}$. probenecid)

(2) Aqueous procaine penicillin $3 \mathrm{~m} . \mathrm{u}$. fortified by $1 \mathrm{~m} . \mathrm{u}$. crystalline penicillin $\mathrm{G}$ (with 1 g. probenecid)

(3) Aqueous benzyl penicillin $5 \mathrm{~m} . \mathrm{u}$. in 0.5 per cent. lignocaine plus $1 \mathrm{~g}$. probenecid

(4) Aqueous procaine penicillin 2.4 m.u., plus 2 g. phenoxymethyl penicillin, 2 g. phenethicillin, or $1 \mathrm{~g}$. ampicillin by mouth, plus $1 \mathrm{~g}$. probenecid

(5) Chloromycetin succinate $1 \mathrm{~g}$.

(6) Kanamycin 2 g.

(7) Spectinomycin $4 \mathrm{~g}$.

\section{Comment}

Very large injections ( $16 \mathrm{ml}$.)

Has been used without probenecid in the USA (Lucas and others, 1967) but with some failures

Better results on all penicillin schedules expected with probenecid

No blood level data available at this dosage Smaller injection possible $(8.5$ to $12 \mathrm{ml}$.)

Higher peak level

Complete success in Greenland (Lomholt and Berg, 1966) (see Table XXII)

Even smaller injection $(8 \mathrm{ml}$.)

Also smaller injection $(8 \mathrm{ml}$.)

As yet untried in areas of high resistance

Added oral therapy could be used with larger injections as in (1) and (2)

Effective but risk of toxicity too great for general use

Effective so far where used

Very expensive

As successful as $2 \cdot 4$ m.u. procaine penicillin in USA

May need further evaluation in a high resistance area
Cost ${ }^{\star}$ in pence to hospitals in United Kingdom

51.6 wit's probenecid

( 1 g. probenecid costs $8 \cdot 4$ pence)

$46 \cdot 2$ with probenecid

51.9 (including 3.4 for lignocaine and 8.4 for probenecid)

With phenoxymethyl penicillin $38 \cdot 5$;

with phenethicillin $49 \cdot 3$;

with ampicillin 60.2 (including 21.6 for procaine penicillin and 8.4 for probenecid)

$79 \cdot 0$

$600 \cdot 0$

Not yet generally available

Not expected to be cheap

^For comparison 1.2 m.u. procaine penicillin costs 10.8 pence. (Prices may have changed since this paper was written).

(Schedules 2, 4, 6, and 7 may be repeated on the second day in female patients) 
TABLE XXXVI Some suggested schedules requiring only one oral dose to be taken away from the clinic

\author{
Initial schedule \\ (8) Aqueous procaine penicillin
4.8 m.u. \\ with probenecid $1 \mathrm{~g}$.
}

(9) As for 8

(10) As for 8

(11) Fortified aqueous procaine penicillin ( 3 m.u. procaine penicillin, 1 m.u. crystalline penicillin $G$ ) with probenecid $1 \mathrm{~g}$.

(12) As for 11

(13) As for 11

(14) Aqueous procaine penicillin $2.4 \mathrm{~g}$.

plus $1 \mathrm{~g}$. ampicillin

plus 1 g. probenecid
Follow-up dose

2 m.u. (1.25 g.) phenoxymethyl penicillin

with $0.5 \mathrm{~g}$. probenecid after $6 \mathrm{hrs}$

$1.25 \mathrm{~g}$. phenethicillin
with $0.5 \mathrm{~g}$. probenecid after 6
hrs.

hrs.

$1 \mathrm{~g}$. ampicillin

with $0.5 \mathrm{~g}$. probenecid after $6-8$ hrs.

2 m.u. (1.25 g.) phenoxymethyl penicillin

with $0.5 \mathrm{~g}$. probenecid after $6 \mathrm{hrs}$.

$1 \cdot 25$ g. phenethicillin

with $0.5 \mathrm{~g}$. probenecid after $6 \mathrm{hrs}$.

$1 \mathrm{~g}$. ampicillin

with or without $0.5 \mathrm{~g}$. probenecid after 6-8 hrs.

$1 \mathrm{~g}$. ampicillin

plus $0.5 \mathrm{~g}$. probenecid
Comment

For use should Schedule 1 prove ineffective

As for 8

As for 8

For use should Schedule 2 prove ineffective

60.9 with probenecid

55.5 with probenecid

\section{As for 11}

As for 11

For use should Schedule 4 prove ineffective
Cost ${ }^{\star}$ in pence to hospitals in United Kingdom

$80 \cdot 0$ with probenecid

86.0 with probenecid

$74 \cdot 6$ with probenecid

$80 \cdot 7$ with probenecid



64.5 (including 30.2 for ampicillin $\quad 12.7$ for probenecid)

^For comparison 1.2 m.u. procaine penicillin costs 10.8 pence (Schedules 11 to 14 may be repeated on the second day in female patients)

TAB LE XXXVII Possible multiple dosage schedules (for both males and females unless otherwise stated)

\section{Schedule}

(15) 2 m.u. aqueous crystalline penicillin intramuscularly three times a day (24 m.u.)

plus 2 g. probenecid ( $16 \mathrm{~g}$.) twice daily for 4 days

(16) $2.4 \mathrm{~m} . \mathrm{u}$. aqueous procaine penicillin intramuscularly

plus $1 \mathrm{~g}$. probenecid $30 \mathrm{~min}$. before injection and three subsequent doses of $0.5 \mathrm{~g}$. 6-hrly (Total $2.5 \mathrm{~g}$.)

(17) 1 g.t ampicillin orally plus $500 \mathrm{mg}$. four times a day ( 1 day for males; 2 days for females)

(18) As for $17 \dagger$ plus 1 g. probenecid twice daily for 2 days

(19) 1 g. erythromycin orally plus $500 \mathrm{mg}$. four times a day for 1 day (Total 3 g.)

[2 days $-5 \mathrm{~g}$. for females]

(20) $1.5 \mathrm{~g}$. tetracycline hydrochloride orally plus $500 \mathrm{mg}$. four times a day for 4 days (Total $9.5 \mathrm{~g}$.)

(21) $500 \mathrm{mg}$. chloramphenicol orally four times a day for 1 day (can be extended to 2 days for females)
Comment

Used with complete success on promiscuous women in Australia (Wren, 1967)

Admission to hospital necessary

Used with success in Far East (Holmes and others, 1967a)

Three tablets taken away by patient, but these are not an antibiotic

Few reports from Far East

Good results expected or obtained elsewhere

Eight to sixteen capsules taken away by patient

As for 17. Six probenecid tablets taken away by patient

Few reports from Far East

Sensitivity tests indicate likelihood of success

Eight to sixteen tablets taken away by patient

Complete success in Far East but will not reach reported resistant strains as reported by $\mathrm{Ho}$ and Chang (1967)

Not recommended for routine use on account of toxicity

For the occasional multiple failure case only

By far the cheapest

Six to fourteen capsules taken away by patient
Cost ${ }^{\star}$ in pence to hospitals in United Kingdom

260.5 (including 67.5 for probenecid)

$90 \cdot 5$ for males $150 \cdot 8$ for females

$124 \cdot 1$ for males $183 \cdot 4$ for females

$90 \cdot 2$ for males $170 \cdot 4$ for females

\section{$127 \cdot 7$}

$14 \cdot 4$ 